NBER WORKING PAPER SERIES

\title{
THE INFLUENCE OF THE HOME OWNERS' LOAN CORPORATION ON HOUSING MARKETS DURING THE 1930S
}

\author{
Price V. Fishback \\ Alfonso Flores-Lagunes \\ William Horrace \\ Shawn E. Kantor \\ Jaret Treber \\ Working Paper 15824 \\ http://www.nber.org/papers/w15824
}

\section{NATIONAL BUREAU OF ECONOMIC RESEARCH \\ 1050 Massachusetts Avenue \\ Cambridge, MA 02138 \\ March 2010}

The corresponding author is Price Fishback, Department of Economics, University of Arizona, Tucson, AZ 85721, 520-621-4421, pfishback@eller.arizona.edu. The authors are indebted to Larry Neal, Joseph Mason, Michael Haines, and Paul Rhode for their help in obtaining the data for the project. We have benefited from the comments of Charles Courtemanche, Gary Gorton, Chris Hanes, Kei Hirano, Harry Kelejian, Trevor Kollman, Robert Margo, Jonathan Rose, Ken Snowden, John Wallis, Eugene White, David Wheelock and workshop participants at the University of California-Davis, Kentucky, Maryland, Nevada-Las Vegas, the New York University Stern School of Business, North Carolina, Oxford, Royal Holloway, and Yale, as well as participants at the 2001 and 2008 NBER Summer Institutes, the 2010 NBER-DAE program meeting, and the 2001 Economic History Association meetings. Financial support has been provided by National Science Foundation Grants SBR-9708098, SES-0080324, SES 0214483, and SES 0617972, the Earhart Foundation, the University of Arizona Foundation, the University of Arizona Office of the Vice President for Research, and the Frank and Clara Kramer Professorship in Economics at the University of Arizona. The views expressed herein are those of the authors and do not necessarily reflect the views of the National Bureau of Economic Research.

NBER working papers are circulated for discussion and comment purposes. They have not been peerreviewed or been subject to the review by the NBER Board of Directors that accompanies official NBER publications.

(C) 2010 by Price V. Fishback, Alfonso Flores-Lagunes, William Horrace, Shawn E. Kantor, and Jaret Treber. All rights reserved. Short sections of text, not to exceed two paragraphs, may be quoted without explicit permission provided that full credit, including $(\subset$ notice, is given to the source. 
The Influence of the Home Owners' Loan Corporation on Housing Markets During the 1930s Price V. Fishback, Alfonso Flores-Lagunes, William Horrace, Shawn E. Kantor, and Jaret Treber

NBER Working Paper No. 15824

March 2010

JEL No. G28,N12,N42,N9,R31,R38,R51

\begin{abstract}
$\underline{\text { ABSTRACT }}$
Problems with mortgage financing are widely considered to be a major cause of the recent financial meltdown. Several modern programs have been designed to mimic the Home Owners' Loan Corporation of the 1930s. The HOLC replaced the toxic assets on the balance sheets of financial institutions by buying troubled mortgages and then refinanced the mortgages to allow home owners to avoid losing their homes. We analyze the impact of the HOLC on the nonfarm rental and owned home markets after developing a new data set for over 2800 counties in the United States. In counties with fewer than 50,000 people, where financial markets were not as well developed as in larger cities, the HOLC's financial interventions helped stimulate the demand for owned housing more than it influenced the supply. In rental markets the HOLC appears to have contributed to an increase in the supply of rental housing that was likely associated the improvement of the balance sheets of lending institutions.
\end{abstract}

Price V. Fishback

Department of Economics

University of Arizona

Tucson, AZ 85721

and NBER

pfishback@eller.arizona.edu

Alfonso Flores-Lagunes

Food \& Resource Economics Department and Department of Economics

University of Florida

P.O. Box 110240

Gainesville, Florida 32611-0240

alfonsofl@ufl.edu

William Horrace

Center for Policy Research

426 Eggers Hall

Syracuse University

Syracuse, NY 13244-1020

whorrace@maxwell.syr.edu
Shawn E. Kantor

School of Social Sciences, Humanities and Arts

University of California, Merced

5200 N. Lake Road

Merced, CA 95343

and NBER

skantor@ucmerced.edu

Jaret Treber

Dept. of Economics

Kenyon College

Gambier Ohio

jaret@bpa.arizona.edu 


\section{The Influence of the Home Owners' Loan Corporation on Housing Markets During the 1930s}

Problems with mortgage financing are considered to be a major cause of the 2007-2008 financial meltdown (Gorton, 2009). A large share of the "toxic assets" held by financial institutions is composed of an admixture of credit default swaps insuring collateralized debt obligations largely composed of mortgage-backed securities. As the bailout of financial institutions starting in 2008 progressed, the government began developing programs to refinance mortgages. Several programs were introduced in 2008 but were slow to get started. In February 2009, the Obama administration announced the Homes Affordable Modification Program (HAMP), which committed \$75 billion to aid up to 3 or 4 million at-risk homeowners in refinancing into loans with more affordable monthly payments. Through January 2010, the HAMP had made offers of 1.3 million trial modifications, over 940 thousand were active, 117 thousand modifications had been accepted by loan service providers, and approximately 1,000 had been canceled. ${ }^{1}$

How will programs like the HAMP influence housing markets in the longer run? Since the program has several years to run, we will not know for some time. However, we can begin to make forecasts about its impact by examining the impact of the Home Owners' Loan Corporation (HOLC) on non-farm housing markets during the Great Depression. The government allowed the HOLC to issue bonds to purchase from lenders approximately one million nonfarm mortgages that were in danger of foreclosure between 1933 and 1936; therefore, it replaced toxic assets with more secure government 
bonds. In the process the HOLC refinanced the mortgages at better terms for a large number of households that had been in danger of losing their homes. Despite the improved terms, the HOLC eventually foreclosed on 200 thousand of the loans by the early 1940 s.

To date, discussions of the HOLC have largely been descriptive discussions of overall macroeconomic effects (Grebler, Blank, and Winnick, 1956; Harris, 1951). Yet, there was enormous variation in the distribution of HOLC loans and purchases that can be used to identify the influence of the program on housing markets. To the extent that the HOLC refinancing of loans prevented foreclosures, the program likely staved off a decline in the demand for owned housing, prevented a surge in demand for rental housing, and prevented an increase in the supply of both owned housing and rental housing. In addition, the HOLC loan purchases provided more secure assets that could be used as backing for more mortgage loans that would increase the demand for owned housing, as well as make more construction loans that could lead to increases in the supply of rental and owned-home housing.

To measure these effects, we examine how the distribution of HOLC mortgage funds influenced the number of homeowners, renters, rents and the values of owned homes in nonfarm housing markets in nearly three thousand U.S. counties in 1930 and 1940. Using estimates of the effects measured by reduced-form equations, we can measure the summary effects of the HOLC on these markets and make some statements about the relative size of the HOLC's impact on supply and demand shifts. We use an instrumental variable approach to control for endogeneity of the distribution of HOLC funds that might have arisen because the HOLC distributed more funds to areas with 
more troubled markets. The results show no effect of the HOLC in a sample that includes counties of all sizes. When the sample is limited to counties with populations under 50,000, where financial institutions were more focused on local lending, the HOLC appears to have propped up the demand for owned homes and stimulated the supply of rental property.

\section{HOUSING TROUBLES IN THE 1930S}

Housing markets boomed in the 1920s, as building construction and housing prices rose. The horizontal axis of Figure 1 shows the ratio of the value of owneroccupied housing in 1930 to the value of mortgaged owner-occupied housing in 1920 for 278 of the largest cities in the U.S. The average ratio across the cities was about 1.45 . Some cities experienced declines and one outlier in Rhode Island experienced a tripling of prices. These ratios likely understate the boom in housing prices because HOLC surveys of neighborhoods from the mid-1930s report the peak in housing prices as occurring around 1927 in a number of cities (HOLC Area Surveys).

The boom was soon followed by a strong reversal as the housing sector was one of the leading casualties of the Great Depression. Alexander Field (1992) argues that housing markets actually played a key role in contributing to the downturn from 1929 through 1933 and acted as a drag on recovery of GDP and housing after 1933. Figure 1 shows that the housing markets where home values rose more in the 1920s tended to fall more in the 1930s. 
Nationally, housing markets did not recover to 1929 levels to the same extent as the rest of the economy. At the national level, real average personal income and real average retail sales had re-achieved their 1929 values by 1939 , and this was true in a majority of the states. ${ }^{2}$ In contrast, even though the overall CPI in 1940 was 16 percent below its 1930 level, the nominal median value of an owned home in 1940 had fallen 48.6 percent below its 1930 value, and nominal median nonfarm contract rents for rental property had fallen 24 percent (U.S. Bureau of Census 1975, 210-211). Meanwhile, ten years of extra-ordinary unemployment had contributed to a decline in the home ownership rate from 47.8 percent in 1930 to 43.6 percent in 1940. Figures 2 through 4 show that that there was substantial variation in the housing market changes in the 1930s. In fact, there were increases in home ownership rates in several western and southwestern states.

\section{THE HOME OWNERS' LOAN CORPORATION}

The Great Contraction from 1929 through 1933 led to a 30- to 40-percent fall in housing prices, a large number of failures of financial institutions, and a sharp rise in mortgage foreclosures. In response, a large number of states adopted mortgage moratoria that prevented foreclosures. As part of the broad range of New Deal programs established during their First Hundred Days in office, the Roosevelt Administration adopted the HOLC to aid home owners "in hard straits largely through no fault of their own (Federal Home Loan Bank Board 1937, 28).” There were plenty who fit this description because 25 percent of the workforce was unemployed and many others were working less than full time. Between 1933 and 1936 (mostly in 1933 and 1934) the 
HOLC used bonds to purchase 1,017,827 troubled mortgage loans with an average value of $\$ 3,039$ ( $\$ 48,865$ in 2008 dollars) from lenders and then refinanced the loans on better terms for borrowers (Federal Home Loan Bank Board 1939, 125; (Harris 1951, 1) The HOLC rejected over 800 thousand applications, some because the household was not in dire need, others because the borrower was not likely to repay the loan.

The HOLC loans to troubled borrowers more closely resembled modern amortized long-term mortgages than the loans they replaced. Prior to the 1930s most mortgagees were required to place large down payments of between 40 to 60 percent of the property value. The typical mortgage loan required repayment of interest for five years with a balloon payment of the principal at the end of five years. Most loans were refinanced at the end of the five year period. Opportunities to obtain amortized loans were available from some types of lenders. For example, a number of Building and Loans offered a "Philadelphia plan," in which a second amortized mortgage was issued for 30 percent of the value of property after the original loan was obtained. The borrower then repaid interest only on the first loan and the amortized amount on the second mortgage for five years and then could refinance the principal into an amortized loan through the Building and Loan. ${ }^{3}$

The HOLC replaced the five year interest-only loans with fifteen year amortized loans in which the borrower made equal payments throughout the life of the loan. The loan to value ratio was allowed to rise from the traditional 50 percent of the value of the home to 80 percent. In many cases the 80 percent figure was applied to the value of the home from better times, so the true percentage loaned on the value of the house was much higher (Rose, 2009, Harris, 1951, 25). The interest rate on the loans was 5 percent 
when low risk private home loans were offered at 6 to 7 percent. ${ }^{4}$ Borrowers could opt to pay interest only for the first three years of the loan and there was no prepayment penalty.

The typical mortgage refinanced by the HOLC in 1933 was more than two years in default on the principal, due to a combination of forebearance by lenders and state mortgage repayment moratoria. In addition, the typical loan refinanced had not paid taxes on the property for two to three years (Federal Home Loan Bank Board 1938, 27). The HOLC paid delinquent taxes and by 1937 had reconditioned about forty percent of the homes while folding the costs into the principal of the mortgage (Federal Home Loan Bank Board 1938, 29).

People who anticipated that the HOLC would fully resolve the problem likely were disappointed. The mortgage foreclosure rate only fell slightly over the next three years. In June 193639.4 percent of the HOLC borrowers were more than three months behind on their mortgage payments (Federal Home Loan Bank Board 1937, 28). By 1940 the HOLC had foreclosed on 17 percent of its loans. Most of those foreclosures occurred after delinquencies in both principal and interest had run for more than 18 months with taxes unpaid (Federal Home Loan Bank Board 1937, 28). At some point between 1936 and 1940, the HOLC owned and then resold roughly 2 percent of the owner-occupied nonfarm dwellings in the United States. The foreclosed dwellings were eventually sold off at an average loss of 33 percent per foreclosure, as the HOLC sought to avoid roiling housing markets with their sales (Comptroller General of the United States 1950, 11). Based on current mark-to-market accounting standards for financial institutions it is very likely that the HOLC would have been considered insolvent in the late 1930s. 
The HOLC benefitted many home owners who had been in dire straits and the absence of a prepayment penalty allowed many to repay the loan long before the fifteen year period of the loan had ended. When the HOLC was closed down after the last loan was repaid in 1951, the auditor reported that the HOLC had paid net earnings to the U.S. Treasury of \$13.994 million between its inception and June 30, 1952. However, the auditor suggested that the net earnings should not be considered profit. The cost to the Treasury of supplying funds to the Corporation since 1933 was about $\$ 91.9$ million, so "the net overall cost to the Government has been about $\$ 78$ million (Comptroller General of the United States 1953,9$)$. Since the HOLC had added nearly $\$ 60$ million to its balance sheet through investments in savings and loans and in the Federal Savings and Loan Insurance Company, the losses on the HOLC program were probably closer to or more than $\$ 100$ million. ${ }^{5}$

\section{ANTICIPATED EFFECTS OF THE HOLC}

The annual reports about the HOLC suggest that the program was designed to achieve two goals. First, it should insure that homeowners who were in danger of defaulting on their mortgages through "no fault of their own" would be allowed to stay in their homes. Second, by buying the weakened mortgages from mortgage lenders, typically with government bonds, the HOLC was injecting more capital into the lending markets that could insure a continued flow of funds for lending in mortgage markets, residential building, or other types of lending.

Consider the impact of these factors in a demand and supply framework for owned homes and rentals in these local areas. The predictions described here rely on the 
following assumptions. In each year households make the decision whether to move or stay in their current dwelling; therefore, the entire stock of housing is included in the supply and demand analysis for owned housing and rental housing markets. Holding other factors constant, the supplies of owned housing and rental housing have positive slopes, and the demands for each have negative slopes. Even though there is a reasonable degree of substitutability between owned housing and rental housing, there are quality differences in the housing associated with tenure. Thus rents on rental housing and the values of owned homes do not move in lock-step and can even move in different directions when demand and supply shifters in the two markets dictate such a change.

In the owned home market the HOLC potentially had multiple effects on both the demand and supply side of the market. On the demand side of the market, more HOLC financing directly propped up the demand for housing in multiple ways. First, by offering lower interest rates, higher loan to value ratios, and a longer, amortized repayment structure, the HOLC provided troubled borrowers with the funds to stay in their homes. Even in good times, modern studies have shown that relaxation of credit constraints can have a significant impact on the transition to home ownership. ${ }^{6}$ Second, lower interest rates lowered the discount rate used by home buyers and stimulated demand for owned housing by raising the present value of the stream of benefits from the home. Finally, HOLC funds were also used to improve the quality of housing, which in turn, raised the demand for housing. ${ }^{7}$

On the supply side of the market the HOLC relaxed credit constraints on lending by replacing toxic assets with safer HOLC bonds in the lenders' asset portfolios. To the 
extent that the HOLC bonds underwrote construction loans, the supply of housing for ownership would have increased.

After combining these multiple effects, the HOLC loans are anticipated to have stimulated the demand for owned housing, which would have increased values of owned homes and the number of home owners. They also might have stimulated supply, which would have raised the number of home owners and led to lower owned home values. The combined effects would have led to an increase in the number of homeowners and an uncertain effect on price. Prices would have risen if the demand rise dominated the supply rise, fallen if the supply rise dominated the demand rise, and stayed the same if the two shifts offset each other.

In rental markets, the HOLC loans would have been associated with a reduction in demand for rental housing by reducing the number of foreclosure households entering rental markets. On the supply-side, the HOLC also would have reduced the amount of foreclosed property that was temporarily for rent until it could be sold. As a countervailing force on the supply side, the HOLC's purchase of mortgages would have freed up more capital for the construction of rental housing that would have increased the supply of rental housing. The summary effects of the HOLC in the rental market would have been to reduce demand for rental housing and have conflicting effects on the supply-side of the equation. Had the demand change associated with the HOLC dominated, the HOLC would have been associated with lower rents and fewer renters. If the supply reduction dominated, the HOLC would have been associated with higher rents and fewer renters. If the supply increase dominated, the HOLC would have been associated with lower rents and more renters. 
The HOLC's impact on these markets would have been diminished to the extent that the HOLC was forced to foreclose on properties itself. We know that nationwide the HOLC foreclosed on 17 percent of the properties on which it made loans in the 1930s. To the extent that the distribution of foreclosures was the same as that of the flow of HOLC funds, holding constant the other factors in the regression, the effect of the HOLC on the various housing outcome variables should be dampened but the signs not affected.

\section{DATA}

The data set used to study the impact of the HOLC is composed of information from 2854 counties that reported information on all of the following housing variables in the 1920 Integrated Public Microdata Sample, and 1930 and 1940 population and housing censuses (U.S. Bureau of the Census, 1933, 1943): median contract rents for non-farm rentals in 1930 and 1940, median values of nonfarm owned homes in which the owners lived in 1930 and 1940, the number of non-farm renters in 1920, 930 and 1940, and the number of non-farm home owners in, 1920, 1930 and 1940. Information was reported for some of these variables in the remaining counties, but we chose to focus only on counties that reported all of the information so that the sample was consistent across equations estimated. We focus on non-farm monthly contract rents and owned home values because the HOLC was a non-farm program. The monthly contract rent included related expenses, such as utilities and fuels only if they were included in the rental contract. It also included non-cash rent payments (labor, goods, etc) that were converted to a dollar amount. The full contract rent was reported, even when the tenant might have 
been delinquent with the rent. The house values are the owner's estimate of the sale value of the housing unit. For single-family, non-farm houses, the estimates included the value of the house and the land. For owner-occupied units that were part of a building containing other households or businesses, the estimate included the value of only the part where the household resided. ${ }^{8}$

The information on New Deal programs was collected and reported in mimeos by the U.S. Office of Government Reports (1940b) and has been computerized and made available at Price Fishback's website at the University of Arizona. (http://economics.eller.arizona.edu/faculty/fishback.asp) under Datasets from Published Research Projects. Data on the housing value and most other correlates also come from the 1930 and 1940 population censuses and are available in computerized form in ICPSR dataset 2896 (Haines, no date). See the Data Appendix for further information on sources.

\section{EVALUATING THE IMPACT OF THE HOLC}

To investigate the impact of the HOLC funds, we develop two groups of four reduced-form equations that examine the relationships between HOLC funds and the median value of owned nonfarm homes, the median nonfarm contract rent, the number of nonfarm home owners, and the number of nonfarm renters, while controlling for other correlates that were likely to influence nonfarm housing markets. For brevity of exposition, we show the equations with owned home housing values as the dependent variables. The equations for the other three housing measures have the same structure but with different coefficients and error terms. 
The first set of equations treats the analysis as a cross-section from 1940 with no dynamic feature to show the results from a more sophisticated version of the types of comparisons of means that were commonly performed for programs by New Deal administrators to show the impact of their programs in the late 1930s.

$\mathrm{HV}_{\mathrm{i}, 40}=\beta_{1} \mathrm{HOLC}_{\mathrm{i}, 33-36}+\gamma_{1} \mathrm{X}_{\mathrm{i}, 40}+\alpha_{1} \mathrm{~S}_{\mathrm{s}, 40}+\theta_{1, \mathrm{i}}+\mathrm{u}_{1, \mathrm{i}, 40}$.

Where $\mathrm{HV}_{\mathrm{i}, 40, \mathrm{k}}$ is the median value of owned housing in county $\mathrm{i}$ in $1940 . \mathrm{HOLC}_{\mathrm{i}, 33-36}$ is the annual value of HOLC loans distributed between 1933 and 1936 per person in 1930, $\mathrm{X}_{\mathrm{i}, 40}$ is a Mx1 vector of $\mathrm{M}$ measured factors, including other New Deal programs that influence the supply and demand of rental housing and of owned housing in $1940 . \mathrm{S}_{\mathrm{s}, 40}$ is a 47x1 vector of time-varying state policies that were common influences on housing markets in the counties in state s. The vector $\theta_{1, \mathrm{i}}$ captures a set of supply and demand factors that are unmeasured, time-invariant, and idiosyncratic to each county. The error term, $\mathrm{u}_{1, \mathrm{i}}$ captures stochastic error and other time-varying unmeasured factors. The coefficient $\beta_{1}$ measures the marginal impact of the HOLC spending on the housing variable, $\gamma_{1}$ is a $1 \mathrm{xM}$ vector of coefficients for the measured influences of the New Deal and $\alpha_{1}$ is a $1 \times 47$ vector of coefficients for the state dummy variables.

We can control for the unmeasured, time-invariant county factors, $\theta_{\mathrm{k}, \mathrm{i}}$ by taking difference between the values in 1940 and the values in 1930. We therefore estimate the following equations.

$\Delta \mathrm{HV}_{\mathrm{i}, 40, \mathrm{k}}=\beta_{\mathrm{k}} \mathrm{HOLC}_{\mathrm{i}, 33-36}+\gamma_{\mathrm{k}} \Delta \mathrm{X}_{\mathrm{i}, 40}+\alpha_{\mathrm{k}} \Delta \mathrm{S}_{\mathrm{s}, 40}+\Delta \mathrm{u}_{\mathrm{k}, \mathrm{i}, 40}$ 
Since there were no HOLC loans prior to 1930, the change in HOLC loans is the same as the level of HOLC loans in 1933 to 1936. In the analysis, we capture the changes in state tax and real estate policies $\Delta \mathrm{S}_{\mathrm{s}, 40-30}$ with a series of 47 state dummy variables.

Since housing is one of the most durable of goods and there is considerable inertia in housing decisions, it is likely that there will be strong persistence across time in the housing measures. ${ }^{9}$ Therefore, we estimate a second set of equations to capture the persistence in the nature of the housing markets across time by adding lagged values from 1930 to the analysis. It can easily be shown that if the structural owned home and rental demand and supply equations that include past rents, owned home values, and the number of homeowners and renters in one or more equations, then each of the reduced form equations will be functions of all four of the past housing measures. Therefore, each of the reduced form equations with persistence will take the form in equation 3. For this example, the dependent variable is the owned home value in county $i$ in 1940 $\left(\mathrm{HV}_{\mathrm{i}, 40)}\right.$.

$$
\begin{gathered}
\mathrm{HV}_{\mathrm{i}, 40}=\beta_{1} \mathrm{HOLC}_{\mathrm{i}, 33-36}+\gamma_{1} \mathrm{X}_{\mathrm{i}, 40}+\alpha_{1} \mathrm{~S}_{\mathrm{s}, 40}+\theta_{1, \mathrm{i}}+\delta_{11} \mathrm{MR}_{\mathrm{i}, 30}+\delta_{21} \mathrm{R}_{\mathrm{i}, 30}+\delta_{31} \mathrm{H}_{\mathrm{i}, 30} \\
+\delta_{41} \mathrm{HV}_{\mathrm{i}, 30}+\mathrm{v}_{1, \mathrm{i}, 40 .}
\end{gathered}
$$

$\mathrm{H}_{\mathrm{i}, 30}$ represents the number of nonfarm homeowners, $\mathrm{R}_{\mathrm{i}, 30}$ is the number of nonfarm renters, $\mathrm{HV}_{\mathrm{i}, 30}$ is the median value of nonfarm homes and $\mathrm{MR}_{\mathrm{i}, 30}$ is the median rent on nonfarm rental property. After differencing, the equation becomes

$$
\begin{gathered}
\Delta \mathrm{H}_{\mathrm{i}, 40-30}=\beta_{1} \Delta \mathrm{HOLC}_{\mathrm{i}, 33-36}+\gamma_{1} \Delta \mathrm{X}_{\mathrm{i}, 40-30}+\alpha_{1} \Delta \mathrm{S}_{\mathrm{s}, 40-30}+\delta_{11} \Delta \mathrm{MR}_{\mathrm{i}, 30-20}+\delta_{21} \Delta \mathrm{R}_{\mathrm{i}, 30-20} \\
+\delta_{31} \Delta \mathrm{H}_{\mathrm{i}, 30-20}+\delta_{41} \Delta \mathrm{HV}_{\mathrm{i}, 30-20}+\Delta \mathrm{v}_{1, \mathrm{i}, 40} .
\end{gathered}
$$


We calculated measures of the number of nonfarm homeowners and nonfarm renters in 1920 for the counties by aggregating up from the IPUMS sample (University of Minnesota). Since the census of 1920 did not collect information on rents or home values, we use annual earnings per employed wage worker in manufacturing as a proxy for rents and home value. ${ }^{10}$

\section{An Instrument for HOLC Loans}

The differenced analyses above controls for many of the time-invariant features that might have led to omitted-variables bias in the analysis. However, there still remains the potential of endogeneity bias arising from the way the HOLC distributed its housing loans. The HOLC bought and refinanced troubled loans. To the extent that there were more troubled loans in areas where housing values and home ownership were falling in the mid-1930s, the coefficient on the HOLC is likely to be biased in a negative direction in the change in home ownership and change in housing value regressions. The bias in the change in rent and change in renter equations is less certain because the distribution of HOLC loans would have been influenced indirectly by what was happening in the home ownership markets. If the number of troubled loans that drew HOLC attention in the mid-1930s were associated with foreclosure trends that led to foreclosed homes becoming rental property and to more renters, the HOLC spending would have been related to rising rental demand and rental supply. The combination would have had offsetting impacts on rents but would have been associated with more renters. Thus, the endogeneity bias for the HOLC loans might have been positive in the number of renters equation and uncertain in the rent equation. 
To combat these potential problems with endogeneity, we sought an instrument for the distribution of HOLC funds that is strongly correlated with HOLC funding but is not correlated with the error term in the difference equations with state fixed effects above. One way to approach this is through the administrative side. The HOLC established 244 offices across the country with at least one in each state. Given the paperwork associated with the loans and the inspections of property required, it seems likely that it was more costly for borrowers who were more distant from the HOLC offices to refinance their loans through the HOLC. It would be more costly to seek the mortgage refinancing and more costly for HOLC workers to evaluate the value of the property and administer loan information related to it. Therefore, as a start, we calculated the difference in miles between the county seat of a county and the nearest county seat of a county where the HOLC office was located. So that the value of the instrument would have a positive relationship with the HOLC funds, we used the inverse of the distance.

There still remains a potential problem if the HOLC chose the office locations on the basis of the number of troubled mortgages in the area. It is not clear how the HOLC would know this information except through using information that we have already included in the regression for 1930, which was the previous census period. Most of the nationwide information that would have been available for 1933-1934 was not collected until the New Deal programs like the CWA and the FERA collected information, and they did not collect information on housing until 1934. The one area where they might have an accurate assessment might have been the building permit information collected by the BLS for over 200 cities. ${ }^{11}$ 
To avoid the potential problem of endogeneity in the choice of HOLC office locations, we use an alternative strategy for picking offices as an instrument. As a starting point for the location of federal offices in each state, a federal government that was trying to minimize its administrative costs in each state would have started by choosing to put an office in the state's seat of political power, the state capital. The next most likely location would have been the county with the largest population in the state, so that they could reach the most people possible. Following the same strategy, if they added another office in each state it would be in the second largest city. To add another office, it would be in the third largest city, etc. In this alternative formulation, then we developed an artificial administrative version of the HOLC that placed HOLC offices in all state capitals and in the four largest cities in each state. After determining the distance from the nearest artificial office to each county, we then chose the instrument to be the inverse of the distance from the nearest artificial office in the state. In cases where the office was in the county and the distance was zero, we counteracted this problem by adding one mile to all distances before taking the inverse. ${ }^{12}$

The artificial geographic distribution of HOLC offices matches the actual distribution to a reasonable degree. The actual HOLC offices were dispersed across 228 counties (some had more than one), while the artificial distribution puts offices in 204 counties. There are 137 counties that had an HOLC office and also would have had an artificial office; 91 counties had an actual HOLC office but would not have had an artificial office; and 67 counties had no HOLC office but would have had an artificial office. $^{13}$ 
The additional correlates in the analysis are listed in Appendix Table 1. The HOLC coefficient estimates are therefore estimates of the relationship of the HOLC with the housing variables holding constant a variety of measures of economic activity, the age distribution, race, immigrant status, illiteracy, as well as other New Deal programs that might have influenced housing markets. To the extent that there are feedback effects from changes in the housing markets to economic activity and/or to the New Deal programs, the coefficients of economic activity and of New Deal programs in the equations might be subject to endogeneity bias. So far, we have been unable to develop a full set of instruments that have enough strength to control for the endogeneity bias in all of the programs simultaneously. In estimating the effect of the HOLC, we chose to control for potential omitted-variable bias related to these programs by including them in the analysis. There is a risk that endogeneity bias in estimation of the other New Deal coefficients might spill over into the HOLC coefficient. ${ }^{14}$

\section{RESULTS}

Plots of the raw data offer a preview of some of the findings from the estimation. The plots in Figures 2 and 3 suggest positive relationships between the average value of HOLC loans per capita from 1933 through 1936 and both the median value of nonfarm owned homes and the number of nonfarm home owners for counties with less than 50,000 people in 1940 . The graphs focus on counties with less than 50,000 people so that it is not dominated by a few very large cities that disguise the pattern. When the plots control for a variety of unmeasured time-invariant factors by looking at the change in home values and in the number of homeowners in Figures 4 and 5, the positive relationship of the HOLC loans with housing values and number of homeowners is no 
longer present. The same patterns are generally present in plots of median rents and the number of renters. The estimation procedures go further by controlling for time-varying covariates, persistence, and also by controlling for endogeneity using instrumental variables.

The approach to the estimation that best matches what Roosevelt officials typically followed in evaluating programs would be to run the regressions with the levels in 1940 as a function of the HOLC per capita expenditures. This approach leads to the conclusion that the HOLC worked well. The results in line 1 of Table 1 suggest that areas with more per capita HOLC spending had higher home values and more homeowners. The directions of change are consistent with a view that the HOLC raised owned home demand more than it changed the supply of owned homes. In the rental market areas with more HOLC spending had higher rents and fewer renters, which implied that HOLC spending lowered the supply of rental housing by staving off foreclosures more than it reduced rental demand. All of the coefficients are statistically significant. The coefficient of 50.9 for home values implies that an extra dollar in annual per capita HOLC spending was associated with home values that were $\$ 50.9$ higher. Elasticities estimated at the means are 0.08 for house values, 0.27 for the number of owners, 0.05 for rents, and -0.24 for the number of renters.

The cross-sectional coefficients are potentially biased by endogeneity, persistence effects, unmeasured time-invariant features of the housing markets that are not controlled for in the 1940 cross-section. Courtemanche and Snowden (2009) show that HOLC spending was distributed to areas with higher home values and with higher home ownership rates. Therefore, the cross-sectional results for 1940 might be just mimicking 
the positive relationships that originally influenced the distribution of HOLC funds in the mid-1930s.

We estimated the 1940 cross section to control for persistence in the housing market by including 1930 housing values, rents, nonfarm renters, and nonfarm homeowners in each of the equations. When these factors are included in line 2 of Table 1 , the coefficient of housing values falls below zero and the coefficient of the number of homeowners is cut sharply and is no longer statistically significant. In the rental market the rent coefficient changes sign so that the coefficients of rent and the number of renters are both negative and statistically significant.

We also estimated the model to control for unmeasured time-invariant heterogeneity by differencing between 1940 and 1930. These results, reported in line 3 of Table 1, show that HOLC spending was associated with lower housing values and rents and had no statistically significant relationship with the difference in the number of homeowners or renters. A similar set of results arise from the estimation when we estimate a persistence model with differencing as in line 4 in Table 1 . These results suggest that the HOLC was associated with a decline in demand that was greater than the rise in supply in the owned home market and a decline in demand that was greater than the rise in supply in the rental market.

The results from the differenced models with and without persistence are still likely to be affected by endogeneity bias if the distribution of HOLC loans was influenced by the changes in the housing market between 1930 and 1936 . Our expectation is that the HOLC distributed more loans to areas with the most troubled loans, and thus areas where housing values and the number of homeowners were falling 
and where the number of renters was rising and rents were falling. We therefore estimated the differenced models using the instrument based on the inverse of distance from the nearest artificial office described above. Tests of the strength of the instrument using the Kliebergen-Paap statistic suggest that strength of the instrument is not a problem if we are willing to accept weak instrument bias of 10 percent in the IV differenced estimation in line 5 and 15 percent in the IV differenced with persistence estimation in line 6.

The results from the IV differenced estimation without taking persistence into account suggest that the HOLC was associated with reductions in housing values and the number of owners, reductions in rents and more renters. The estimation that deals with unmeasured time-invariant heterogeneity, persistence, and endogeneity of the HOLC fully is the differenced IV estimation with differences in housing variables between 1930 and 1920 incorporated. The results show no statistically significant effect of the HOLC on housing markets. The coefficients are all relative small and suggest elasticities with respect to the HOLC of -0.05 for housing values, 0.13 for the number of nonfarm homeowners, -0.02 for rents, and 0.03 for the number of nonfarm renters.

The estimates in Table 1 include all cities in the sample. There were likely to be differences in the responsive to HOLC changes based on the size of the counties. Even as late as the $1930 \mathrm{~s}$, there were differences in access to capital markets based on the size of the population in the county and state. There still remained significant variation across states in the interest rates charged by banks on loans (Bodenhorn, 1996, 2010). Further, many of the failures of banks and building and loans in the 1920s and in the 1930s were failures of relatively small institutions reliant on local lending. The smaller 
was the population in the county, the less likely that the loan portfolio of local mortgage lenders would be diversified across larger geographic markets or across a broader economic structural base.

Although we include these factors as controls in the estimations summarized in Table 1 for all cities, there is no consideration of how the HOLC coefficient itself might vary across different county sizes. To explore what happens with smaller cities we have re-estimated the models using various groupings of county sizes. The estimates for counties with fewer than 50,000 people in 1930 are reported in Table 2. As we add counties with increasingly larger populations to the sample of counties with fewer than 50,000 people, the results have a tendency to move in the direction of the results reported in Table 1. As was the case with the estimates for the entire sample, the coefficient estimates and the implied shifts in demand and supply in the housing markets change markedly as we add controls for persistence, difference the equations, and use IV estimation. The IV estimates for the differenced models both with and without controls for persistence in lines 5 and 6 have the same signs and are similar in size so we will focus on the results controlling for persistence.

In counties with fewer than 50,000 people the point estimates of the coefficients imply that a rise in demand was the dominant influence of the HOLC in the owned home market. The HOLC coefficients for owned home values and the number of homeowners are both positive and statistically significant at the 10 percent level or better. The elasticities with respect to per capita HOLC spending are 0.153 for the values of owned homes and 0.111 for the number of home owners. In the rental market, a rise in the supply of rental housing may have more than offset a rise in the demand for rental 
housing. More HOLC funds were associated with a statistically significant rise in the number of nonfarm renters and a statistically insignificant decline in rents with respective elasticities of 0.159 and -0.023 .

In an independent study of the values of owned homes and home ownership rates in the 1930s, Charles Courtemanche and Kenneth Snowden (2009) also find that the HOLC was associated with higher values of owned homes. They use an alternative measure of HOLC lending, the ratio of HOLC loans made between 1933 and 1936 relative to owned homes in 1930, and have some different control variables. They estimate the relationship of the HOLC lending rate with owned home values and home ownership rates in 1940 in a cross-sectional analysis that includes the lagged housing measures from 1930. As an instrumental variable, they use a measure of whether the county was within 30 miles of an HOLC office. Their results also show a rise in housing values for smaller counties. $^{15}$

\section{CONCLUSIONS}

Between 1933 and 1936, the HOLC purchased over one million nonfarm mortgage loans from lenders and then refinanced the loans. Its dual purpose was to replace the toxic assets on mortgage lenders' books and to help homeowners who were in danger of defaulting through no fault of their own stay in their homes. If the HOLC had worked as expected, the HOLC would have raised both the demand and the supply in the owned home market and would have reduced demand and either raised or lowered supply in rental markets. 
If someone were to rely on plots of housing market variables in 1940 against per capita HOLC spending in 1933-1936 or a cross-sectional multi-variate regression analysis in 1940 with controls for economic activity and state policies, they would argue that the HOLC was a success. In the nonfarm owned home market more HOLC loans were associated with higher owned home values and more home owners. This would imply that the HOLC stimulated a demand increase for owned homes that more than offset any increases in the supply of owned homes. In the regression analysis of the rental market, the HOLC loans were higher in areas with higher rents and lower numbers of renters. Such a finding is consistent with a view that the HOLC prevented foreclosures that would have driven rents down and the number of renters up.

The impact of the HOLC diminishes a great deal once we control for timeinvariant heterogeneity, persistence effects, and the endogeneity of the distribution of HOLC funds. In the estimation including counties of all sizes, there are no statistically significant effects of the HOLC.

There are institutional reasons to believe that the HOLC might have been more effective in smaller counties where financial markets were more local and many financial institutions were oriented to local lending and thus were less diversified across sectors of the economy. When the sample is restricted to counties with populations under 50,000 people, the HOLC contributed to a rise in demand in the owned home market that more than offset changes in supply in that market. Thus, the HOLC seems to have worked as expected in the owned home market by preventing a drop in demand for owned housing, although the elasticities of home value and the number of home owners with respect to HOLC lending were each less than 0.16. In nonfarm rental markets in counties with 
fewer than 50,000 people, the results suggest that a rise in supply of rental housing may have more than offset changes in demand. The results suggest room for further research on lending decisions made by the mortgage holders whose toxic loans were replaced by HOLC bonds.

What lessons can we learn from the HOLC about how the HAMP program will influence modern housing markets? First, the HAMP appears to be moving faster than the HOLC. The HOLC was created in June 1933 and did not make its first few loans until late in the year, although it made the vast majority of its one million loans in the calendar year of 1934. The HAMP was created in February 2009 and had offered about 400,000 modifications by mid-summer; it has offered 1 million modifications in its first year, although only 116 thousand are finalized. Given that the HOLC had to build an organization from scratch, improved communications technology, and the government's much larger role in modern markets, we might have higher expectations for the HAMP in terms of speed of operation.

Second, we should expect that the HAMP will likely lose money in the long run and experience periods where there are a significant number of people aided who are behind on their new mortgages or defaulting. The HOLC loan program lost money. Within 3 years of the start of the HOLC more than one-third of the borrowers who received refinancing were behind by three or more months on their mortgage payments. Within 6 years the HOLC had foreclosed on 20 percent of its loans and was heavily involved in renting the foreclosed housing and trying to time the resales to avoid influencing housing values. On the other hand, the current economic crisis is much less 
severe than the Great Depression, which should aid in reducing the eventual number of foreclosures that the HAMP will face.

Third, the effects of the HAMP might not be as strong as those of the HOLC because the strongest effects of the HOLC were in smaller counties with less access to deep financial markets in the 1930s. Local financial markets are much more tightly integrated into the national and world financial markets in the modern era, and thus there is much greater access to mortgage credit today throughout the country than in the 1930 s, even after controlling for the different severities of the crises. Finally, there are likely to be effects on rental markets and other financial markets that are larger than might be anticipated initially. 
Figure 1

1940/1930 Ratio of Average Owned Home Values Plotted Against the 1930/1920 Ratio of Average Home Values for 272 U.S. Cities

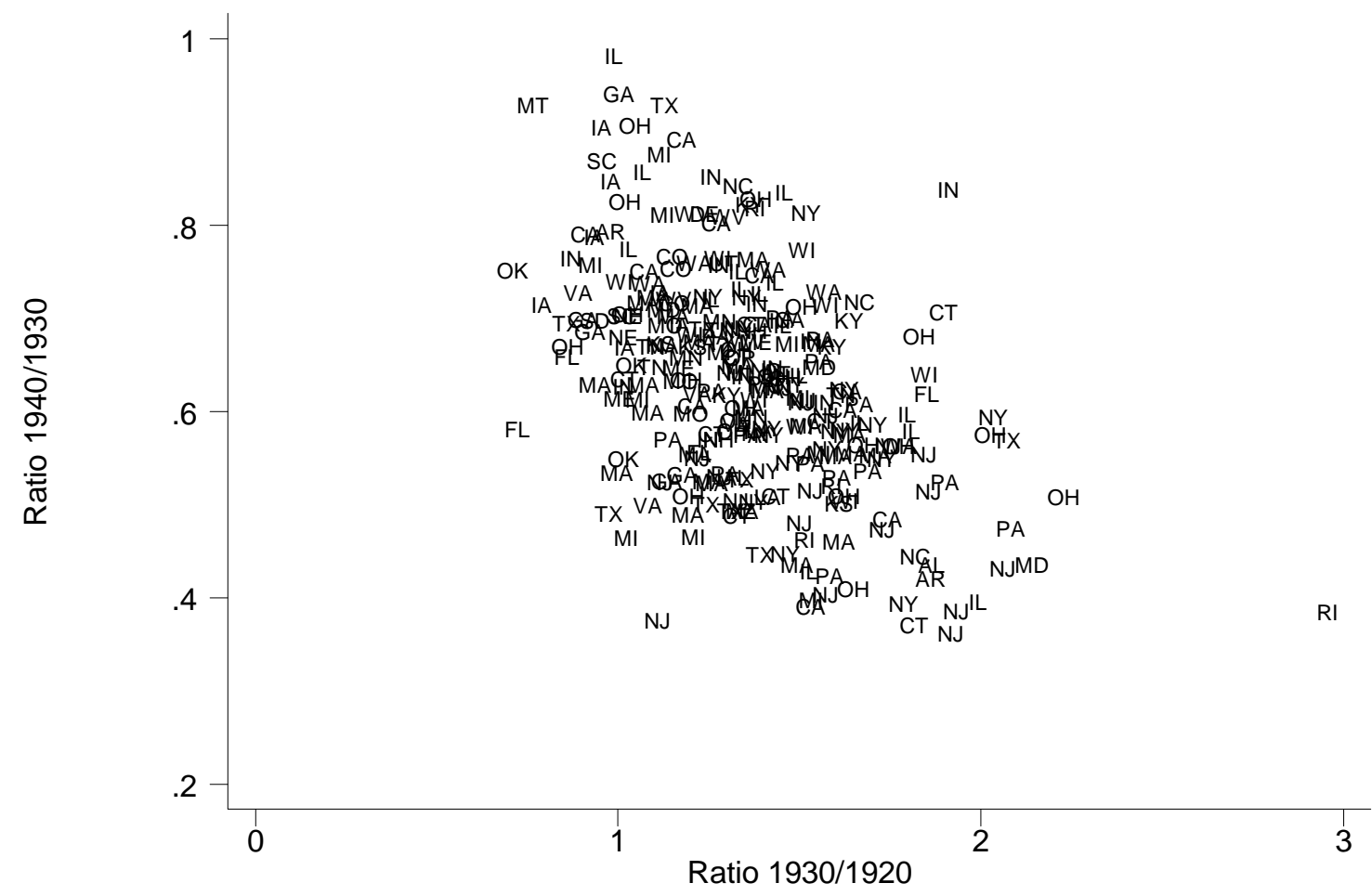

Source:. Each city is represented by the state abbreviation for the state where it is located. Average Owned Home Values in 1940 and 1930 are calculated using the IPUMS Household Samples. Average Owned Home Value in 1920 is only for mortgaged homes from the 1920 Mortgaged Home Survey (U.S. Bureau of the Census, 1923). 
Figure 2

Plot of Median Value of Owned Homes in 1940 Against Annual Value of HOLC Loans Per Capita in 1933-1936 for Counties with Less than 50,000 People

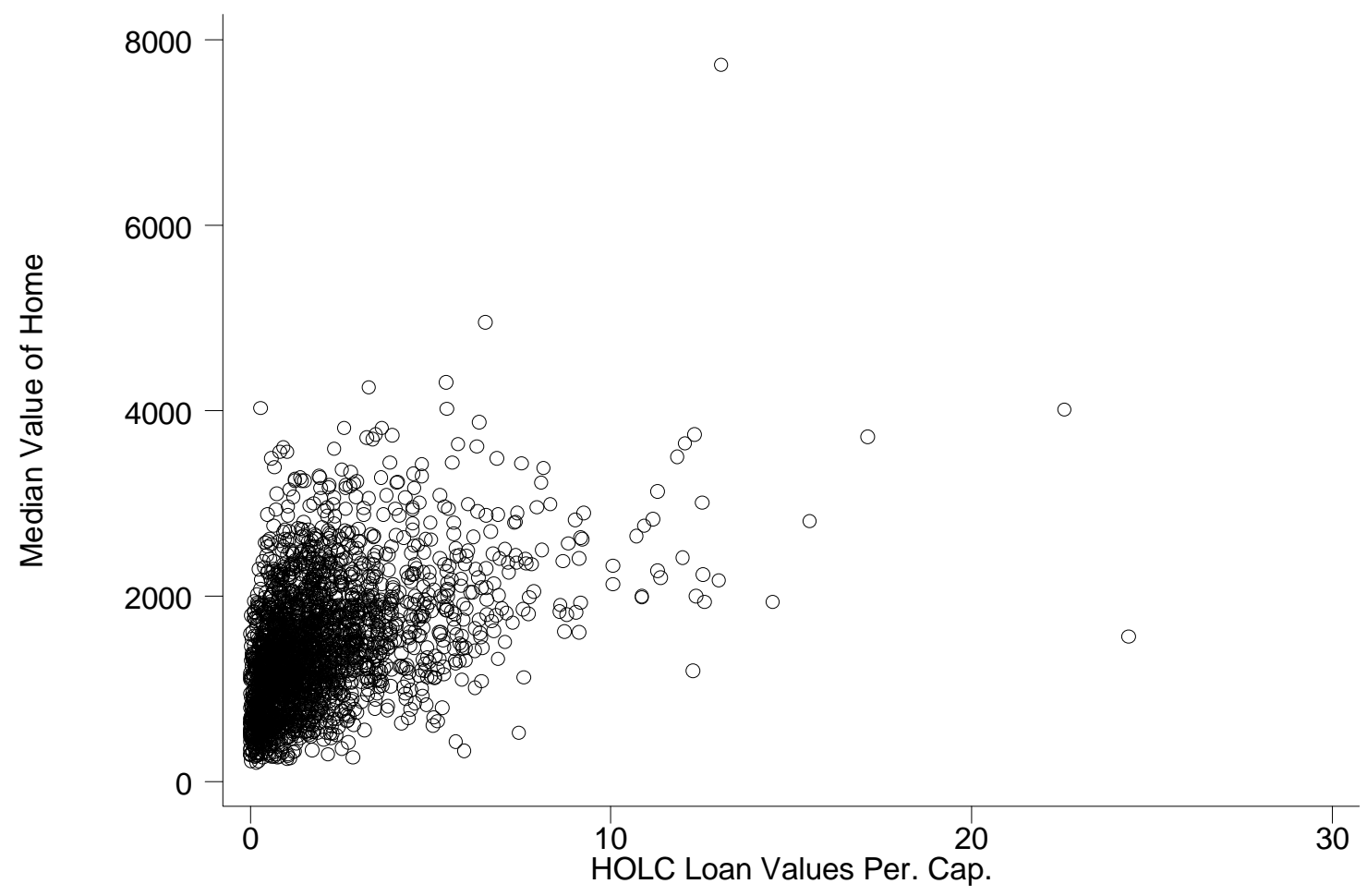




\section{Figure 3}

Plot of Number of Nonfarm Home Owners in 1940 Against Annual Value of HOLC Loans Per Capita in 1933-1936 for Counties with Less than 50,000 People

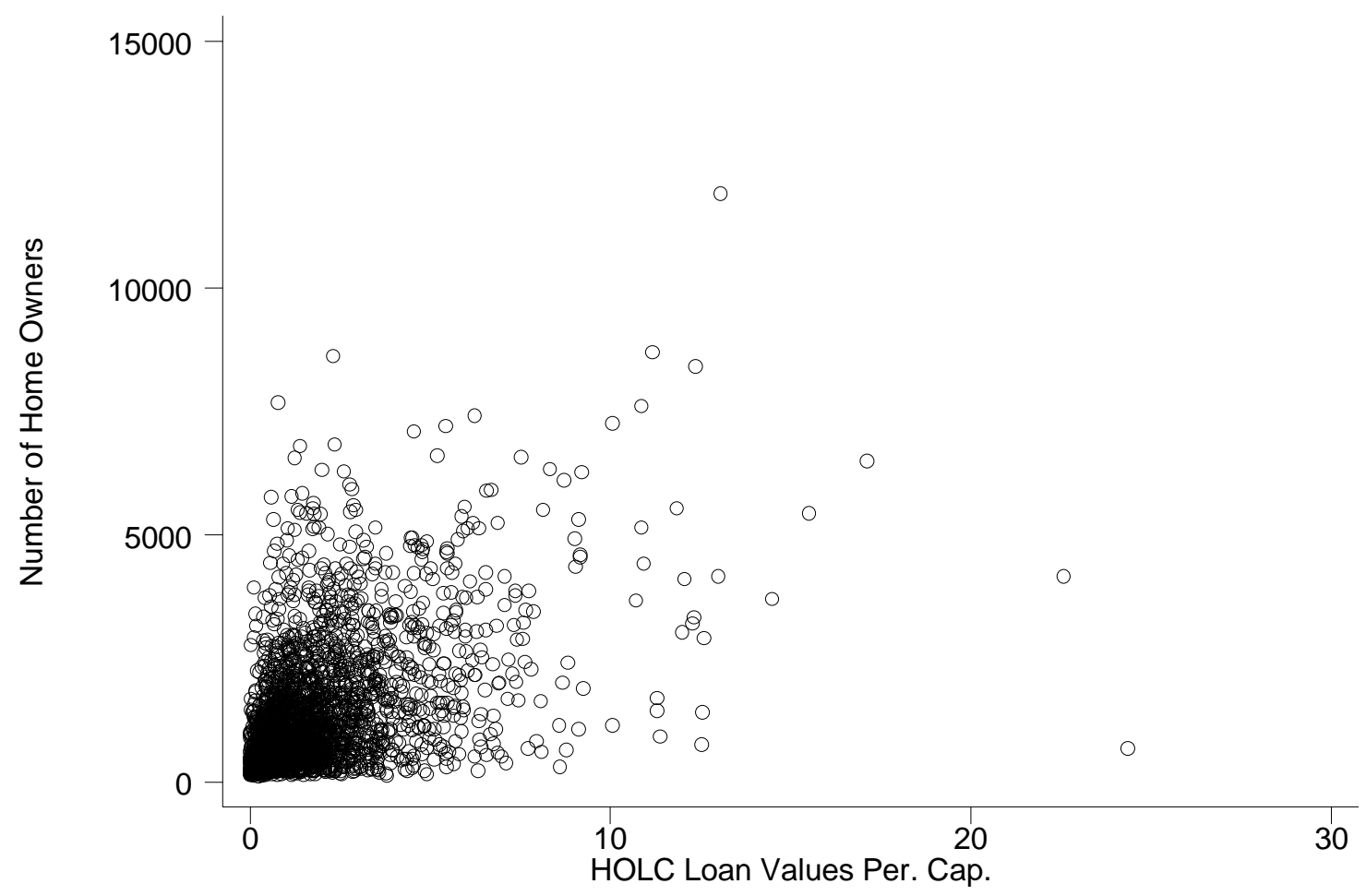


Figure 4

Plot of Change in Median Value of Owned Homes 1940-1930 Against Annual Value of HOLC Loans Per Capita in 1933-1936 for Counties with Less than 50,000 People

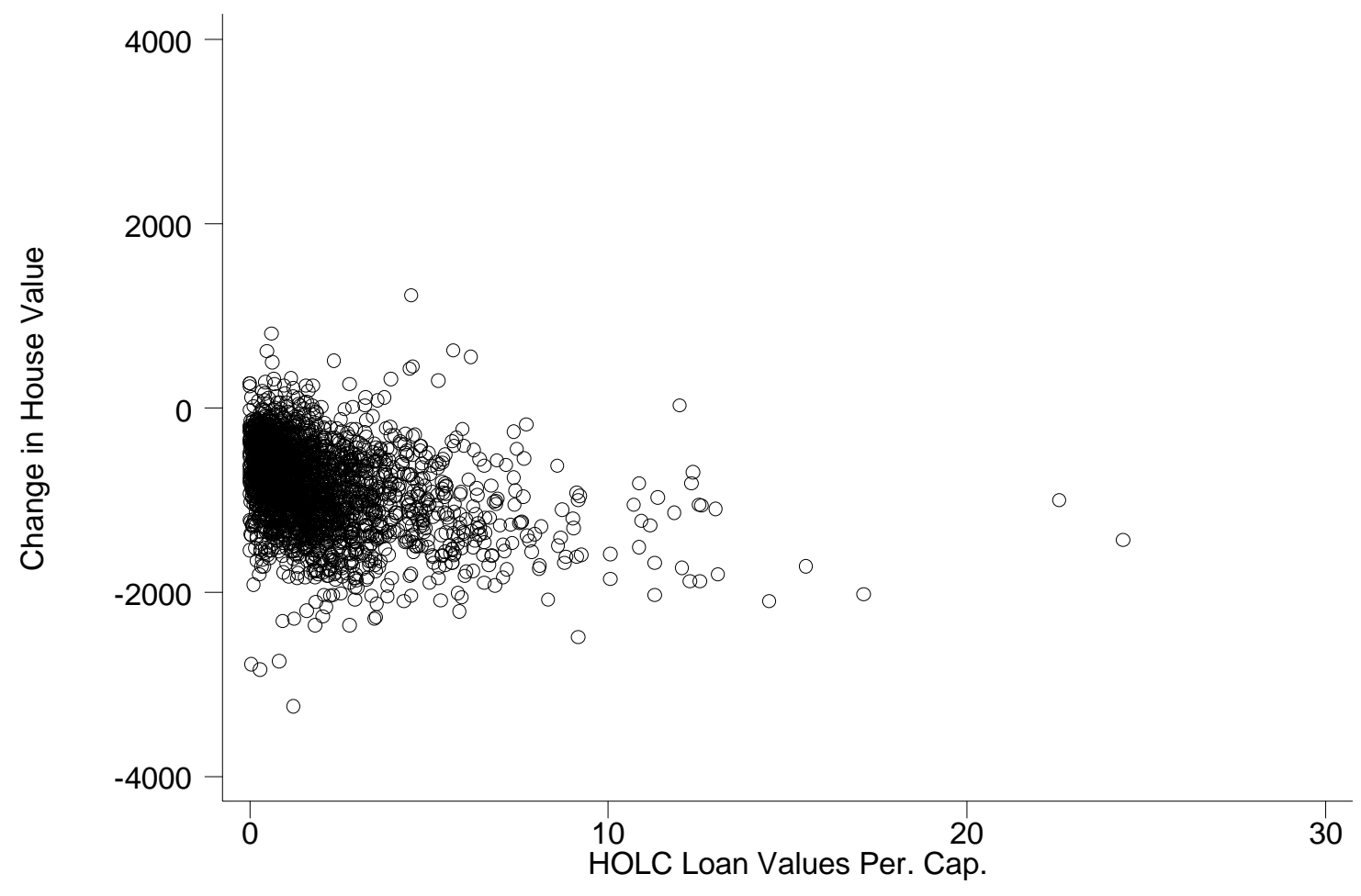




\section{Figure 5}

Plot of Change in Number of Nonfarm Home Owners 1940-1930 Against Annual Value of HOLC Loans Per Capita in 1933-36 for Counties with Less than 50,000 People

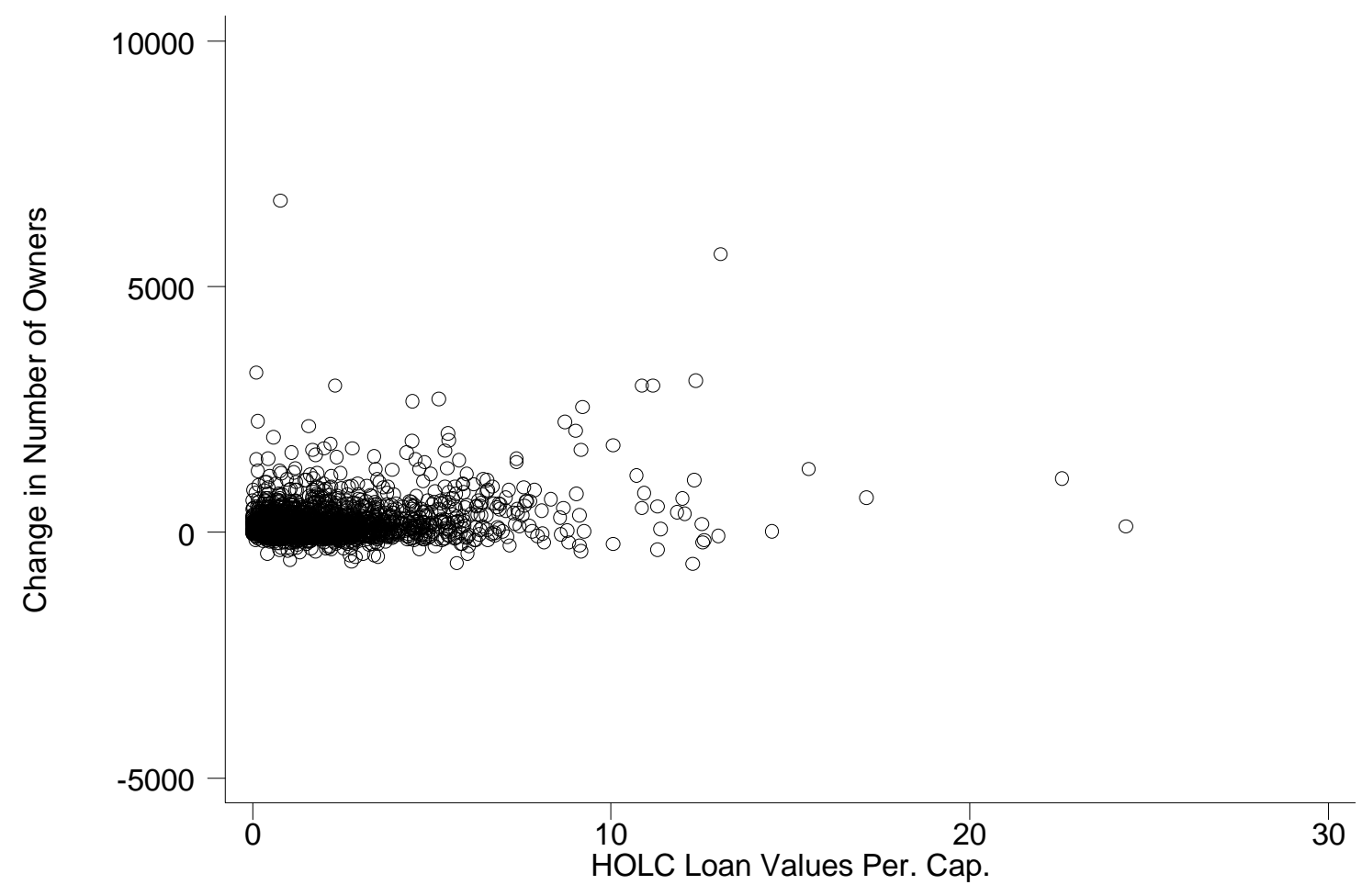


Table 1

Coefficients for the Annual Value of Per Capita HOLC Loans from Various Estimation Procedures for Counties of All Sizes

\begin{tabular}{|c|c|c|c|c|c|c|}
\hline Line & & & $\begin{array}{l}\text { Value } \\
\text { Owned } \\
\text { Home }\end{array}$ & $\begin{array}{l}\text { Number } \\
\text { Home } \\
\text { Owners }\end{array}$ & Rent & $\begin{array}{l}\text { Number } \\
\text { of } \\
\text { Renters }\end{array}$ \\
\hline \multirow[t]{3}{*}{1} & \multirow[t]{3}{*}{ Level 1940} & Coefficient & 50.9 & 412.7 & 0.228 & -525.0 \\
\hline & & t-statistic & 4.74 & 2.67 & 4.45 & -3.04 \\
\hline & & Elasticity & 0.079 & 0.266 & 0.053 & -0.237 \\
\hline \multirow[t]{3}{*}{2} & \multirow{3}{*}{$\begin{array}{l}\text { Level } 1940 \text { with Lagged } \\
\text { Housing Variables }\end{array}$} & Coefficient & -8.4 & 54.4 & -0.073 & -61.8 \\
\hline & & t-statistic & -1.48 & 0.69 & -2.39 & -1.81 \\
\hline & & Elasticity & -0.013 & 0.035 & -0.017 & -0.028 \\
\hline \multirow[t]{3}{*}{3} & \multirow[t]{3}{*}{ Differenced 1940-1930 } & Coefficient & -60.1 & 16.5 & -0.231 & -12.2 \\
\hline & & t-statistic & -7.59 & 0.32 & -6.62 & -0.1 \\
\hline & & Elasticity & -0.094 & 0.011 & -0.054 & -0.005 \\
\hline \multirow[t]{3}{*}{4} & \multirow{3}{*}{$\begin{array}{l}\text { Differenced 1940-1930 with } \\
\text { Lagged Differences of Housing } \\
\text { Variables 1930-1920 }\end{array}$} & Coefficient & -56.7 & 62.4 & -0.212 & -189.7 \\
\hline & & t-statistic & -7.75 & 1.27 & -6.63 & -2.12 \\
\hline & & Elasticity & -0.088 & 0.040 & -0.049 & -0.086 \\
\hline \multirow[t]{3}{*}{5} & \multirow[t]{3}{*}{ IV: Differenced 1940-1930 } & Coefficient & -62.7 & -196.7 & -0.273 & 1429.5 \\
\hline & & t-statistic & -2.35 & -0.79 & -2.29 & 2.07 \\
\hline & & Elasticity & -0.098 & -0.127 & -0.064 & 0.645 \\
\hline \multirow[t]{3}{*}{6} & \multirow{3}{*}{$\begin{array}{l}\text { IV: Differenced 1940-1930 } \\
\text { with Lagged Differences of } \\
\text { Housing Variables 1930-1920 }\end{array}$} & Coefficient & -30.4 & 208.7 & -0.090 & 61.6 \\
\hline & & t-statistic & -1.04 & 1.07 & -0.65 & 0.16 \\
\hline & & Elasticity & -0.047 & 0.134 & -0.021 & 0.028 \\
\hline
\end{tabular}

Notes. There were 2857 observations. Each level estimation equation includes the list of correlates in 1940 or 1939 levels listed in Appendix Table 1. The level estimation with lagged housing variables also adds the median nonfarm owned home values, median nonfarm rents, the number of nonfarm homeowners, and the number of nonfarm renters in 1930 to the list of correlates. Each differenced estimation includes the list of correlates in change form in Appendix Table 2. The differenced estimation with lagged housing variables also adds the changes in the annual average earnings of manufacturing wage workers from 1919 to 1929 , and the changes in the number of nonfarm home owners and renters from 1920 to 1930.

The Kleibergen-Paap Wald rank F-statistics for the first stage test of strength of the instrument is 19.39 for the IV estimation in line 5, and 10.03 for the IV estimation in line 6. The critical value for the tests of weak instrument strength is 16.38 if one is willing to accept a maximum of 10 percent weak instrument bias, 8.96 for 15 percent bias, and 6.66 for 20 percent bias. 
Table 2

Coefficients for the Annual Value of Per Capita HOLC Loans from Various

Estimation Procedures for Counties with Fewer than 50,000 People in 1930

\begin{tabular}{|c|c|c|c|c|c|c|}
\hline Line & & & $\begin{array}{l}\text { Value } \\
\text { Owned } \\
\text { Home }\end{array}$ & $\begin{array}{l}\text { Number } \\
\text { Home } \\
\text { Owners }\end{array}$ & Rent & $\begin{array}{l}\text { Number } \\
\text { of } \\
\text { Renters }\end{array}$ \\
\hline \multirow[t]{3}{*}{1} & \multirow[t]{3}{*}{ Level 1940} & Coefficient & 63.6 & 43.8 & 0.155 & 16.7 \\
\hline & & t-statistic & 4.89 & 3.00 & 2.26 & 1.43 \\
\hline & & Elasticity & 0.084 & 0.060 & 0.030 & 0.021 \\
\hline \multirow[t]{3}{*}{2} & \multirow{3}{*}{$\begin{array}{l}\text { Level } 1940 \text { with Lagged } \\
\text { Housing Variables }\end{array}$} & Coefficient & 3.3 & 11.3 & -0.088 & 5.1 \\
\hline & & t-statistic & 0.42 & 1.13 & -2.09 & 0.73 \\
\hline & & Elasticity & 0.004 & 0.015 & -0.017 & 0.007 \\
\hline \multirow[t]{3}{*}{3} & \multirow[t]{3}{*}{ Differenced 1940-1930 } & Coefficient & -55.7 & 6.0 & -0.268 & 42.9 \\
\hline & & t-statistic & -8.69 & 1.27 & -8.07 & 5.87 \\
\hline & & Elasticity & -0.074 & 0.008 & -0.052 & 0.055 \\
\hline \multirow[t]{3}{*}{4} & \multirow{3}{*}{$\begin{array}{l}\text { Differenced 1940-1930 with } \\
\text { Lagged Differences of Housing } \\
\text { Variables 1930-1920 }\end{array}$} & Coefficient & -50.5 & 2.0 & -0.234 & 29.8 \\
\hline & & t-statistic & -7.62 & 0.44 & -7.27 & 4.66 \\
\hline & & Elasticity & -0.067 & 0.003 & -0.045 & 0.038 \\
\hline \multirow[t]{3}{*}{5} & \multirow[t]{3}{*}{ IV: Differenced 1940-1930 } & Coefficient & 84.1 & 75.1 & -0.215 & 127.0 \\
\hline & & $t$-statistic & 1.61 & 1.93 & -1.09 & 3.15 \\
\hline & & Elasticity & 0.111 & 0.102 & -0.042 & 0.162 \\
\hline \multirow[t]{3}{*}{6} & \multirow{3}{*}{$\begin{array}{l}\text { IV: Differenced 1940-1930 } \\
\text { with Lagged Differences of } \\
\text { Housing Variables 1930-1920 }\end{array}$} & Coefficient & 115.7 & 81.5 & -0.132 & 123.7 \\
\hline & & t-statistic & 1.8 & 1.83 & -0.58 & 2.77 \\
\hline & & Elasticity & 0.153 & 0.111 & -0.026 & 0.157 \\
\hline
\end{tabular}

Sources and Notes. There were 2463 counties in the sample. The Kleibergen-Paap Wald rank F-statistics for the first stage test of strength of the instrument is 10.28 for the IV estimation in line 5, 7.40 for the IV estimation in line 6 . The critical value for the tests of weak instrument strength is 16.38 if one is willing to accept a maximum of 10 percent weak instrument bias, 8.96 for 15 percent bias, and 6.66 for 20 percent bias. 


\section{Data Appendix}

The New Deal program information is from the U.S. Office of Government Reports (1940b). The data on the nonfarm contract rents, sale value of nonfarm owneroccupied homes, number of renters, number of owners are from the 1930 census volume on Families (volume 6) and the 1940 census volume on Housing (U.S. Bureau of the Census 1933, 1943) and in computerized form in Haines ICPSR 2896. The information on the population, retail sales, wholesale sales, value of crops, mining output, and the percents black, foreign-born, illiterate, urban, and rural nonfarm are from the 1930 and 1940 Censuses and are available in computerized from in Haines (no date). Information on average annual manufacturing earnings in 1919 and 1929 used in the differenced model with persistence comes from the 1920 and 1930 Censuses and is also available in the Haines (no date) compilation of data. The variable was created by dividing total wage expenditures by the average number of employees. For counties with missing observations on manufacturing earnings, we inserted state averages. Information on age distributions in 1930 and 1940 comes from the population censuses and in computerized form from Gardner and Cohen (1992). The infant mortality rate information comes from information on births and infant deaths from the volumes on births, deaths, infant deaths and stillbirths (The U.S. Bureau of the Census, various years). Information on the number of tax returns in the county for 1940 is from Rand McNally (1943); for 1930 it comes from U.S. Bureau of Internal Revenue (1932). The difference in the infant mortality Rate is between the years 1940 and 1933 to include information on Texas and South Dakota, which did not report infant deaths and births by county until 1933. The differences for the per capita measures of retail sales, wholesale sales, mining, and value 
of crops are for the years 1939 and 1929. The mining information was collected from the published Censuses of 1930 and 1940. Information on the location and timing of introduction of HOLC offices was collected from the Home Owners' Loan Corporation Minutes from 1933 through 1935. 


\section{Appendix Table 1}

OLS Regression Results for Level Regressions with 1930 Housing Values with Means and Standard Deviations for Counties with Fewer than 50,000 People in 1930

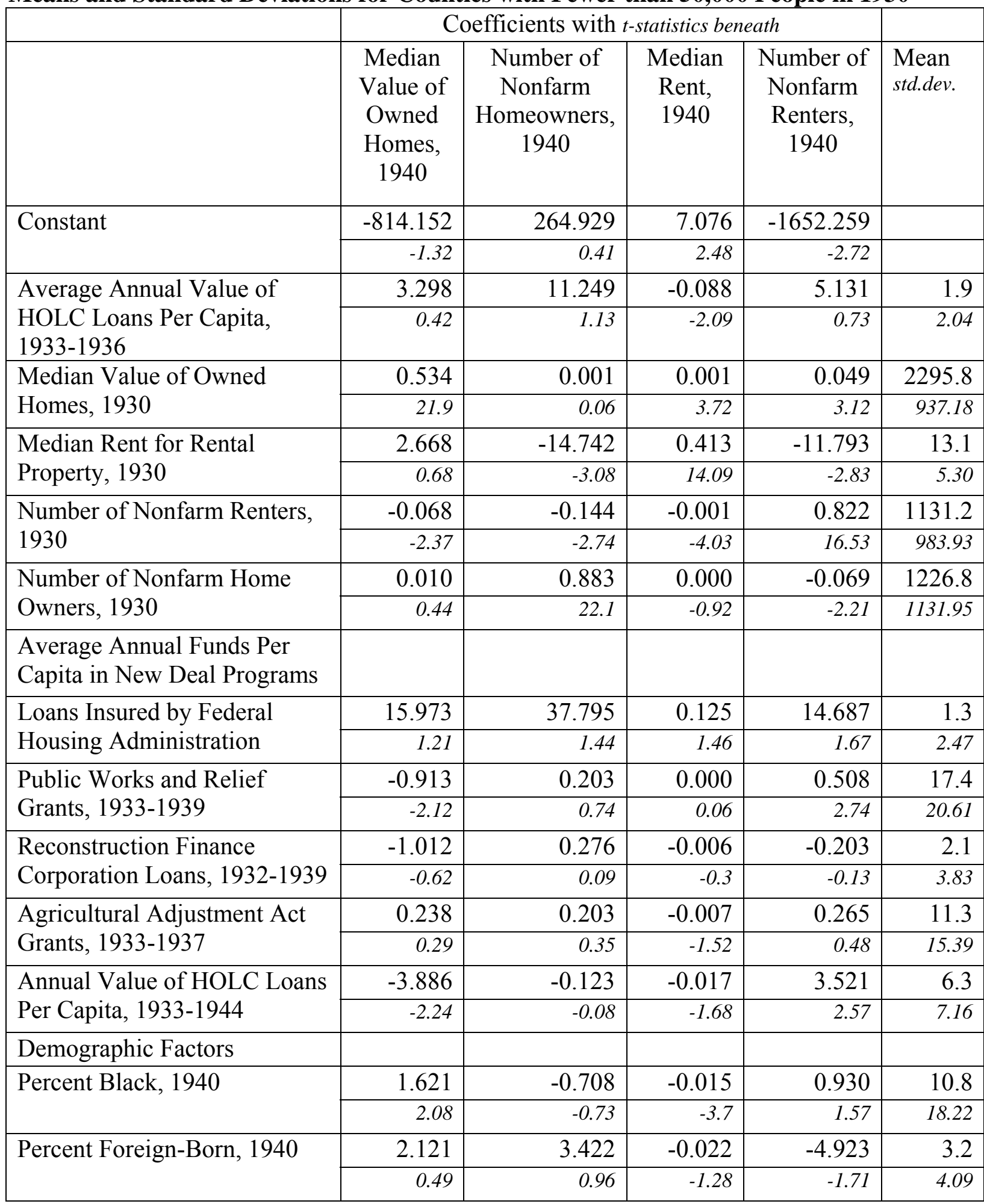




\begin{tabular}{|c|c|c|c|c|c|}
\hline \multirow[t]{2}{*}{ Percent Illiterate, 1940} & 2.845 & -6.233 & -0.006 & -6.167 & 5.8 \\
\hline & 1.05 & -2.12 & -0.24 & -2.15 & 5.11 \\
\hline \multirow[t]{2}{*}{ Percent Urban, 1940} & -2.675 & 4.741 & 0.011 & 6.871 & 18.5 \\
\hline & -2.97 & 3.41 & 1.93 & 6.18 & 20.05 \\
\hline \multirow[t]{2}{*}{ Percent Rural Nonfarm, 1940} & -4.825 & 6.229 & 0.002 & 6.623 & 31.8 \\
\hline & -4.24 & 4.14 & 0.38 & 4.88 & 16.04 \\
\hline \multicolumn{6}{|l|}{$\begin{array}{l}\text { Percentage of Population in } \\
\text { Different Age Categories }\end{array}$} \\
\hline \multirow[t]{2}{*}{$10-19$} & 1.164 & -16.744 & -0.230 & 0.182 & 20.1 \\
\hline & 0.08 & -1.26 & -3.61 & 0.02 & 2.43 \\
\hline \multirow[t]{2}{*}{$20-29$} & 27.680 & -21.658 & 0.106 & 15.561 & 16.3 \\
\hline & 3.06 & -2.15 & 1.89 & 1.79 & 1.58 \\
\hline \multirow[t]{2}{*}{$30-34$} & 9.975 & 17.855 & 0.240 & 98.487 & 6.9 \\
\hline & 0.47 & 0.74 & 2.09 & 4.45 & 0.76 \\
\hline \multirow[t]{2}{*}{$35-44$} & 23.449 & 17.373 & -0.092 & 8.871 & 12.0 \\
\hline & 1.39 & 1.23 & -1.37 & 0.65 & 1.23 \\
\hline \multirow[t]{2}{*}{$45-54$} & -6.301 & -36.347 & -0.081 & -10.046 & 10.5 \\
\hline & -0.57 & -3.65 & -1.32 & -1.16 & 1.67 \\
\hline \multirow[t]{2}{*}{$55-64$} & 5.937 & -11.426 & -0.230 & -15.905 & 7.8 \\
\hline & 0.43 & -1.12 & -4.21 & -1.69 & 1.76 \\
\hline \multirow[t]{2}{*}{ 65up } & 28.865 & -19.258 & 0.015 & 25.115 & 7.3 \\
\hline & 2.01 & -2.06 & 0.27 & 2.89 & 2.32 \\
\hline \multicolumn{6}{|l|}{ Economic Activity Variables } \\
\hline \multirow[t]{2}{*}{ Retail Sales Per Capita, 1939} & -0.297 & 0.105 & 0.005 & 0.469 & 208.0 \\
\hline & -1.1 & 0.37 & 4.13 & 2.47 & 104.31 \\
\hline \multirow[t]{2}{*}{ Tax Returns Per Capita, 1940} & 4676.675 & 2583.398 & 27.710 & 81.558 & 0.05 \\
\hline & 5.03 & 2.76 & 4.51 & 0.18 & 0.04 \\
\hline \multirow[t]{2}{*}{ Population, 1940 (thousands) } & 4.891 & 29.518 & 0.061 & 39.268 & 19.9 \\
\hline & 2.31 & 4.78 & 4.56 & 7.58 & 11.83 \\
\hline \multirow{2}{*}{$\begin{array}{l}\text { Infant Deaths per } 1000 \text { Life } \\
\text { Births, } 1940\end{array}$} & -0.204 & -0.344 & -0.003 & 0.108 & 49.0 \\
\hline & -0.86 & -1.93 & -1.85 & 0.56 & 24.18 \\
\hline \multirow{2}{*}{$\begin{array}{l}\text { Value of Crops per Capita, } \\
1939\end{array}$} & -0.069 & -0.542 & -0.002 & -0.478 & 91.5 \\
\hline & -0.35 & -3.79 & -1.59 & -3.99 & 69.03 \\
\hline \multirow[t]{2}{*}{ Mine output per Capita, 1939} & 0.008 & -0.116 & 0.000 & -0.231 & 35.5 \\
\hline & 0.18 & -2.49 & -1.8 & -4.92 & 169.19 \\
\hline \multirow{2}{*}{$\begin{array}{l}\text { Wholesale Sales per Capita, } \\
1939\end{array}$} & 0.123 & -0.009 & 0.000 & 0.067 & 106.1 \\
\hline & 2.22 & -0.15 & 0.48 & 1.08 & 131.11 \\
\hline \multicolumn{6}{|l|}{ State Dummies } \\
\hline \multirow[t]{2}{*}{ Maine } & -40.7 & 266.3 & 0.2 & -133.9 & \\
\hline & -0.5 & 3.06 & 0.43 & -2.21 & \\
\hline
\end{tabular}




\begin{tabular}{|c|c|c|c|c|}
\hline \multirow[t]{2}{*}{ Massachusetts } & 210.1 & 246.4 & 0.9 & 32.5 \\
\hline & 2.01 & 3.01 & 1.59 & 0.53 \\
\hline \multirow[t]{2}{*}{ New Hampshire } & 232.5 & 354.6 & 0.9 & 108.9 \\
\hline & 3.56 & 4.22 & 1.87 & 2.07 \\
\hline \multirow[t]{2}{*}{ Rhode Island } & 393.9 & 424.0 & 1.5 & 260.4 \\
\hline & 8.95 & 7.83 & 5.11 & 8.58 \\
\hline \multirow[t]{2}{*}{ Vermont } & 215.2 & 124.5 & 0.1 & -31.8 \\
\hline & 3.15 & 1.88 & 0.22 & -0.66 \\
\hline \multirow[t]{2}{*}{ Delaware } & 501.9 & 130.8 & -0.4 & 256.5 \\
\hline & 4.36 & 1.08 & -0.64 & 2.9 \\
\hline \multirow[t]{2}{*}{ New Jersey } & 132.6 & -17.0 & 0.2 & 255.9 \\
\hline & 1.45 & -0.13 & 0.31 & 4.06 \\
\hline \multirow[t]{2}{*}{ New York } & 146.9 & 28.9 & 0.5 & 104.8 \\
\hline & 1.77 & 0.39 & 0.96 & 1.91 \\
\hline \multirow[t]{2}{*}{ Pennsylvania } & 111.7 & 169.4 & 0.2 & 148.0 \\
\hline & 1.37 & 2.06 & 0.31 & 2.79 \\
\hline \multirow[t]{2}{*}{ Illinois } & -85.4 & 388.8 & -0.8 & 223.7 \\
\hline & -1.17 & 4.45 & -1.6 & 3.62 \\
\hline \multirow[t]{2}{*}{ Indiana } & 64.5 & 371.8 & -0.3 & 190.1 \\
\hline & 0.76 & $\begin{array}{l}3.74 \\
\end{array}$ & -0.6 & 2.84 \\
\hline \multirow[t]{2}{*}{ Michigan } & 165.7 & 457.6 & 0.7 & 117.0 \\
\hline & 2.09 & 4.44 & 1.12 & 1.48 \\
\hline \multirow[t]{2}{*}{ Ohio } & 152.8 & 194.8 & -0.3 & 130.2 \\
\hline & 1.81 & 2.03 & -0.51 & 2 \\
\hline \multirow[t]{2}{*}{ Wisconsin } & 117.7 & 369.0 & 0.0 & 136.4 \\
\hline & 1.36 & 3.77 & -0.07 & 1.81 \\
\hline \multirow[t]{2}{*}{ Iowa } & -266.3 & 406.0 & -1.0 & 135.1 \\
\hline & -3.46 & 4.54 & -1.89 & 2.13 \\
\hline \multirow[t]{2}{*}{ Kansas } & -106.9 & 337.6 & -0.9 & 171.0 \\
\hline & -1.22 & 3.32 & -1.43 & 2.42 \\
\hline \multirow[t]{2}{*}{ Minnesota } & 97.4 & 482.7 & 0.1 & 93.4 \\
\hline & 1.19 & 4.84 & 0.21 & 1.22 \\
\hline \multirow[t]{2}{*}{ Missouri } & -140.6 & 425.1 & -1.3 & 240.3 \\
\hline & -1.62 & 4.01 & -2.19 & 3.26 \\
\hline \multirow[t]{2}{*}{ Nebraska } & -301.0 & 333.3 & -1.6 & 241.1 \\
\hline & -3.34 & 3.48 & -2.7 & 3.52 \\
\hline \multirow[t]{2}{*}{ North Dakota } & -73.0 & 429.1 & -0.1 & 327.5 \\
\hline & -0.92 & 4 & -0.19 & 4.36 \\
\hline \multirow[t]{2}{*}{ South Dakota } & -277.3 & 442.4 & -1.3 & 315.4 \\
\hline & -3.14 & 4.24 & -1.92 & 4.34 \\
\hline
\end{tabular}




\begin{tabular}{|c|c|c|c|c|}
\hline \multirow[t]{2}{*}{ Virginia } & 260.0 & 335.4 & -0.7 & 69.8 \\
\hline & 2.33 & 2.95 & -1.18 & 0.79 \\
\hline \multirow[t]{2}{*}{ Alabama } & -16.8 & 190.2 & -2.7 & -33.7 \\
\hline & -0.15 & 1.54 & -4.47 & -0.33 \\
\hline \multirow[t]{2}{*}{ Arkansas } & -188.4 & 326.5 & -2.5 & 143.7 \\
\hline & -1.7 & 2.66 & -3.86 & 1.58 \\
\hline \multirow[t]{2}{*}{ Florida } & 42.2 & 600.5 & -2.4 & 105.2 \\
\hline & 0.37 & 4.97 & -3.7 & 1.32 \\
\hline \multirow[t]{2}{*}{ Georgia } & 136.5 & 417.3 & -2.1 & 216.4 \\
\hline & 1.12 & 3.63 & -3.29 & 2.67 \\
\hline \multirow[t]{2}{*}{ Louisiana } & -182.8 & 584.0 & -2.0 & 36.9 \\
\hline & -1.56 & 4.4 & -3.26 & 0.35 \\
\hline \multirow[t]{2}{*}{ Mississippi } & -119.2 & 281.9 & -2.6 & 46.8 \\
\hline & -1.02 & 2.28 & -4.05 & 0.48 \\
\hline \multirow[t]{2}{*}{ North Carolina } & 58.6 & 319.4 & -1.8 & 107.8 \\
\hline & 0.5 & 2.51 & -2.87 & 1.11 \\
\hline \multirow[t]{2}{*}{ South Carolina } & 378.1 & 243.4 & -1.6 & 94.0 \\
\hline & 3.29 & 1.93 & -2.47 & 0.94 \\
\hline \multirow[t]{2}{*}{ Texas } & -291.7 & 443.7 & -2.6 & 137.7 \\
\hline & -2.71 & 3.8 & -4.31 & 1.58 \\
\hline \multirow[t]{2}{*}{ Kentucky } & 42.1 & 398.0 & -1.2 & 223.0 \\
\hline & 0.44 & 3.55 & -1.85 & 2.93 \\
\hline \multirow[t]{2}{*}{ Maryland } & 308.3 & 363.3 & 0.8 & 113.8 \\
\hline & 2.85 & 3.44 & 1.51 & 1.36 \\
\hline \multirow[t]{2}{*}{ Oklahoma } & -236.2 & 438.6 & -1.7 & 113.2 \\
\hline & -2.4 & 3.57 & -2.58 & 1.37 \\
\hline \multirow[t]{2}{*}{ Tennessee } & 7.1 & 341.4 & -2.3 & 112.5 \\
\hline & 0.07 & 2.87 & -3.66 & 1.29 \\
\hline \multirow[t]{2}{*}{ West Virginia } & 167.2 & 282.4 & -0.7 & 103.1 \\
\hline & 1.77 & 2.91 & -1.2 & 1.53 \\
\hline \multirow[t]{2}{*}{ Arizona } & -82.3 & 367.0 & -0.1 & -98.5 \\
\hline & -0.79 & 3.09 & -0.2 & -1.15 \\
\hline \multirow[t]{2}{*}{ Colorado } & -102.2 & 475.4 & 0.0 & 222.8 \\
\hline & -0.99 & 4.49 & 0.01 & 2.94 \\
\hline \multirow[t]{2}{*}{ Idaho } & -41.0 & 611.6 & 0.0 & 117.6 \\
\hline & -0.38 & 5.36 & -0.05 & 1.43 \\
\hline \multirow[t]{2}{*}{ Montana } & -122.0 & 530.9 & 0.2 & 269.4 \\
\hline & -1.32 & 4.9 & 0.37 & 3.39 \\
\hline \multirow[t]{2}{*}{ New Mexico } & -144.5 & 21.0 & -0.7 & 81.4 \\
\hline & -1.19 & 0.16 & -1.23 & 0.71 \\
\hline
\end{tabular}




\begin{tabular}{|l|r|r|r|r|l|}
\multirow{3}{*}{ Nevada } & -34.9 & 549.4 & -0.2 & 209.0 & \\
\cline { 2 - 6 } & -0.31 & 4.37 & -0.34 & 2.27 & \\
\hline \multirow{3}{*}{ Wyoming } & 355.2 & 555.0 & 0.6 & 21.1 & \\
\cline { 2 - 6 } & 2.9 & 4.48 & 0.86 & 0.25 & \\
\hline California & -56.2 & 323.0 & -0.2 & -29.0 & \\
\cline { 2 - 6 } & -0.48 & 2.9 & -0.35 & -0.33 & \\
\hline Oregon & -222.0 & 391.7 & -1.0 & 349.8 & \\
\cline { 2 - 6 } & -2.02 & 2.61 & -1.85 & 3.61 & \\
\hline Washington & -189.4 & 583.1 & -0.4 & 148.3 & \\
\cline { 2 - 6 } & -1.85 & 5.3 & -0.76 & 1.98 & \\
\hline
\end{tabular}


Appendix Table 2

IV Regression Results for Second- and First-Stage Difference Regressions with Change from 1930-1920 in Housing Values Included for Counties with Fewer Than 50,000 People in 1930, with Means and Standard Deviations

\begin{tabular}{|c|c|c|c|c|c|c|}
\hline & \multicolumn{5}{|c|}{ Coefficients with $t$-statistics beneath } & \\
\hline & \multicolumn{4}{|c|}{ Final Stage: Difference in } & \multirow{2}{*}{ 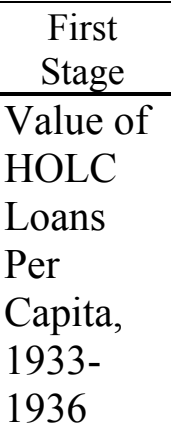 } & \\
\hline & $\begin{array}{c}\text { Median } \\
\text { Value of } \\
\text { Owned } \\
\text { Homes, } \\
1940- \\
1930\end{array}$ & $\begin{array}{c}\text { Number } \\
\text { of } \\
\text { Nonfarm } \\
\text { Home } \\
\text { Owners, } \\
1940- \\
1930\end{array}$ & $\begin{array}{l}\text { Median } \\
\text { Rent, } \\
1940- \\
1930\end{array}$ & $\begin{array}{c}\text { Number } \\
\text { of } \\
\text { Nonfarm } \\
\text { Renters, } \\
1940- \\
1930\end{array}$ & & $\begin{array}{l}\text { Mean } \\
\text { std.dev. }\end{array}$ \\
\hline \multirow[t]{2}{*}{ Constant } & -518.264 & -230.905 & -0.610 & 1.171 & -3.762 & \\
\hline & -1.97 & -1.28 & -0.60 & 0.01 & -9.74 & \\
\hline \multirow{2}{*}{$\begin{array}{l}\text { Average Annual Value of } \\
\text { HOLC Loans Per Capita, } \\
1933-1936\end{array}$} & 115.649 & 81.498 & -0.132 & 123.663 & & 1.91 \\
\hline & 1.80 & 1.83 & -0.58 & 2.77 & & 2.04 \\
\hline \multirow{2}{*}{$\begin{array}{l}\text { One Over Distance from } \\
\text { Nearest Artificial HOLC } \\
\text { Office }\end{array}$} & & & & & 1.426 & \\
\hline & & & & & 3.27 & \\
\hline \multicolumn{7}{|l|}{ Change in } \\
\hline \multirow{2}{*}{$\begin{array}{l}\text { Manufacturing Annual } \\
\text { Earnings of Wage Workers, } \\
1929-1919\end{array}$} & -0.124 & -0.053 & -0.0007 & -0.003 & 0.000 & 30.78 \\
\hline & -2.40 & -2.41 & -4.09 & -0.11 & 0.47 & 220.33 \\
\hline \multirow{2}{*}{$\begin{array}{l}\text { Number of Nonfarm Home } \\
\text { Owners, 1930-1920 }\end{array}$} & -0.189 & -0.062 & -0.0003 & 0.075 & 0.001 & 244.87 \\
\hline & -2.40 & -1.19 & -1.22 & 1.38 & 8.35 & 432.03 \\
\hline \multirow{2}{*}{$\begin{array}{l}\text { Number of Nonfarm Renters, } \\
1930-1920\end{array}$} & -0.173 & 0.002 & -0.0003 & -0.020 & 0.001 & 170.25 \\
\hline & -3.75 & 0.07 & -2.16 & -0.65 & 5.31 & 432.53 \\
\hline \multicolumn{7}{|l|}{ New Deal Grants per Capita } \\
\hline \multirow{2}{*}{$\begin{array}{l}\text { Loans Insured by Federal } \\
\text { Housing Administration }\end{array}$} & -14.302 & 5.397 & 0.021 & -14.483 & 0.130 & 1.25 \\
\hline & -1.32 & 0.50 & 0.43 & -1.21 & 2.21 & 2.47 \\
\hline \multirow{2}{*}{$\begin{array}{l}\text { Public Works and Relief } \\
\text { Grants, 1933-1939 }\end{array}$} & -0.567 & -0.128 & 0.003 & -0.390 & 0.003 & 17.37 \\
\hline & -1.32 & -0.47 & 0.77 & -0.78 & 1.21 & 20.61 \\
\hline \multirow{2}{*}{$\begin{array}{l}\text { Reconstruction Finance } \\
\text { Corporation Loans, 1932-1939 }\end{array}$} & -11.899 & -4.640 & 0.000 & -4.936 & 0.055 & 2.12 \\
\hline & -2.36 & -1.44 & -0.03 & -1.65 & 3.32 & 3.83 \\
\hline \multirow{2}{*}{$\begin{array}{l}\text { Agricultural Adjustment Act } \\
\text { Grants, 1933-1937 }\end{array}$} & 1.945 & -0.415 & -0.004 & -1.642 & -0.006 & 11.28 \\
\hline & 1.69 & -0.75 & -1.02 & -2.10 & -1.45 & 15.39 \\
\hline
\end{tabular}




\begin{tabular}{|c|c|c|c|c|c|c|}
\hline \multirow{2}{*}{$\begin{array}{l}\text { Annual Value of Farm Loans } \\
\text { Per Capita, 1933-1939 }\end{array}$} & -4.061 & -3.320 & -0.020 & -6.247 & 0.003 & 6.34 \\
\hline & -1.48 & -3.21 & -1.97 & -4.11 & 0.29 & 7.16 \\
\hline \multicolumn{7}{|l|}{$\begin{array}{l}\text { Change in Demographic } \\
\text { Variables }\end{array}$} \\
\hline \multirow[t]{2}{*}{ Percent Black, 1940-19309 } & -4.505 & -20.347 & -0.089 & -13.270 & 0.033 & -0.47 \\
\hline & -0.72 & -3.03 & -2.59 & -2.72 & 1.82 & 1.57 \\
\hline \multirow{2}{*}{$\begin{array}{l}\text { Percent Foreign-Born, 1940- } \\
1930\end{array}$} & 8.424 & -8.613 & 0.117 & -22.165 & 0.072 & -0.92 \\
\hline & 1.11 & -2.02 & 3.75 & -4.49 & 2.91 & 2.14 \\
\hline \multirow[t]{2}{*}{ Percent Illiterate, 1940-1930 } & 2.708 & 3.103 & 0.011 & -5.339 & -0.005 & 0.29 \\
\hline & 0.61 & 1.42 & 0.61 & -2.06 & -0.38 & 2.16 \\
\hline \multirow[t]{2}{*}{ Percent Urban, 1940-1930 } & -12.657 & 10.958 & -0.043 & 27.008 & -0.017 & 2.28 \\
\hline & -4.57 & 7.26 & -3.30 & 15.75 & -2.40 & 6.74 \\
\hline \multirow{2}{*}{$\begin{array}{l}\text { Percent Rural Nonfarm, 1940- } \\
1930\end{array}$} & -13.746 & 11.746 & -0.064 & 25.777 & -0.015 & 0.92 \\
\hline & -5.40 & 8.59 & -5.70 & 15.86 & -2.43 & 7.48 \\
\hline \multicolumn{7}{|l|}{$\begin{array}{l}\text { Change in Percent of } \\
\text { Population in Age Group, } \\
1940-1930\end{array}$} \\
\hline \multirow[t]{2}{*}{$10-19$} & -9.026 & -7.273 & 0.053 & -20.301 & -0.013 & -1.15 \\
\hline & -0.74 & -1.28 & 1.15 & -3.02 & -0.33 & 1.28 \\
\hline \multirow[t]{2}{*}{$20-29$} & -4.828 & -4.204 & 0.243 & 3.983 & -0.009 & 0.84 \\
\hline & -0.34 & -0.67 & 4.73 & 0.49 & -0.19 & 1.55 \\
\hline \multirow[t]{2}{*}{$30-34$} & 34.303 & 5.550 & 0.619 & 28.574 & -0.063 & 0.67 \\
\hline & 1.53 & 0.53 & 7.48 & 2.09 & -0.84 & 0.70 \\
\hline \multirow[t]{2}{*}{$35-44$} & 5.866 & 19.577 & 0.204 & 16.529 & -0.049 & -0.12 \\
\hline & 0.34 & 2.39 & 3.39 & 1.74 & -0.93 & 1.06 \\
\hline \multirow[t]{2}{*}{$45-54$} & -88.219 & 0.987 & -0.057 & 12.717 & 0.180 & 0.51 \\
\hline & -5.08 & 0.09 & -0.83 & 1.16 & 4.23 & 1.03 \\
\hline \multirow[t]{2}{*}{$55-64$} & -60.653 & 22.139 & -0.148 & -4.831 & 0.093 & 0.93 \\
\hline & -4.05 & 2.92 & -2.48 & -0.52 & 2.02 & 0.93 \\
\hline \multirow[t]{2}{*}{65 up } & -71.621 & 19.212 & -0.201 & 40.931 & 0.168 & 1.33 \\
\hline & -3.31 & 1.64 & -2.30 & 3.07 & 2.81 & 0.82 \\
\hline \multicolumn{7}{|l|}{$\begin{array}{l}\text { Change in Economic Activity } \\
\text { Variables }\end{array}$} \\
\hline \multirow{2}{*}{$\begin{array}{l}\text { Retail Sales Per Capita, 1939- } \\
1929\end{array}$} & 1.845 & 0.573 & 0.008 & -0.107 & -0.005 & -53.97 \\
\hline & 4.26 & 2.29 & 5.16 & -0.40 & -6.06 & 61.17 \\
\hline \multirow[t]{2}{*}{$\begin{array}{l}\text { Tax Returns Per Capita, 1940- } \\
1930\end{array}$} & 4100.695 & -596.049 & 5.190 & -383.059 & 23.242 & 0.04 \\
\hline & -2.47 & -0.53 & 0.86 & -0.35 & 7.97 & 0.03 \\
\hline \multirow{2}{*}{$\begin{array}{l}\text { Population, } 1940-1930 \\
\text { (thousands) }\end{array}$} & -5.540 & 94.083 & 0.166 & 93.147 & 0.046 & 1.11 \\
\hline & -0.84 & 13.34 & 4.27 & 15.68 & 2.03 & 2.82 \\
\hline
\end{tabular}




\begin{tabular}{|c|c|c|c|c|c|c|}
\hline \multirow{2}{*}{$\begin{array}{l}\text { Infant Deaths Per } 1000 \text { Live } \\
\text { Births, } 1940 \text { - } 1933\end{array}$} & 0.072 & -0.008 & 0.003 & 0.114 & 0.000 & -9.27 \\
\hline & 0.20 & -0.05 & 2.11 & 0.50 & -0.01 & 25.84 \\
\hline \multirow{2}{*}{$\begin{array}{l}\text { Value of Crops per Capita, } \\
\text { 1939-1929 }\end{array}$} & 78.122 & -22.930 & -0.228 & 29.568 & -0.258 & -0.46 \\
\hline & 2.11 & -1.23 & -1.63 & 1.39 & -2.41 & 0.41 \\
\hline \multirow{2}{*}{$\begin{array}{l}\text { Mine Output per Capita, 1939- } \\
1929\end{array}$} & 278.155 & 77.750 & 0.017 & -3.769 & -0.151 & -0.02 \\
\hline & 1.80 & 0.77 & 0.02 & -0.03 & -0.29 & 0.09 \\
\hline \multirow{2}{*}{$\begin{array}{l}\text { Wholesale Sales Per Capita, } \\
\text { 1939-1929 }\end{array}$} & 3.280 & -0.235 & 0.022 & -2.176 & -0.013 & -0.07 \\
\hline & 0.72 & -0.12 & 1.19 & -0.80 & -0.93 & 2.14 \\
\hline \multicolumn{7}{|l|}{ State Dummy Variables } \\
\hline \multirow[t]{2}{*}{ Maine } & -98.3 & 205.7 & -1.3 & -43.7 & 3.293 & \\
\hline & -0.42 & 1.26 & -1.52 & -0.27 & 7.65 & \\
\hline \multirow[t]{2}{*}{ Massachusetts } & -908.6 & 88.8 & -1.8 & 45.0 & 3.671 & \\
\hline & -2.81 & 0.45 & -1.49 & 0.15 & 2.93 & \\
\hline \multirow[t]{2}{*}{ New Hampshire } & 171.3 & 284.8 & -0.9 & 139.4 & 2.207 & \\
\hline & 0.70 & 1.80 & -1.33 & 0.87 & 3.34 & \\
\hline \multirow[t]{2}{*}{ Rhode Island } & -347.4 & 86.5 & -0.1 & -184.4 & 3.495 & \\
\hline & -1.09 & 0.39 & -0.07 & -0.80 & 2.40 & \\
\hline \multirow[t]{2}{*}{ Vermont } & -69.6 & 129.2 & -0.5 & -91.4 & 2.602 & \\
\hline & -0.32 & 0.91 & -0.66 & -0.63 & 6.39 & \\
\hline \multirow[t]{2}{*}{ Delaware } & 504.0 & -220.9 & -0.9 & 331.7 & 1.619 & \\
\hline & 2.15 & -1.59 & -1.12 & 2.36 & 2.26 & \\
\hline \multirow[t]{2}{*}{ New Jersey } & 28.0 & -85.5 & -1.1 & 141.9 & 1.546 & \\
\hline & 0.08 & -0.59 & -1.19 & 0.61 & 1.74 & \\
\hline \multirow[t]{2}{*}{ New York } & -186.2 & -17.5 & -1.2 & 255.6 & 2.105 & \\
\hline & -1.14 & -0.16 & -1.88 & 2.34 & 5.77 & \\
\hline \multirow[t]{2}{*}{ Pennsylvania } & -54.6 & 95.7 & -1.6 & 226.6 & 2.293 & \\
\hline & -0.31 & 0.84 & -2.47 & 1.93 & 7.62 & \\
\hline \multirow[t]{2}{*}{ Illinois } & 251.3 & 215.0 & -1.5 & 135.2 & 2.318 & \\
\hline & 1.54 & 1.91 & -2.32 & 1.19 & 9.41 & \\
\hline \multirow[t]{2}{*}{ Indiana } & 92.2 & 71.3 & -1.7 & -78.0 & 4.246 & \\
\hline & 0.32 & 0.36 & -1.62 & -0.40 & 10.51 & \\
\hline \multirow[t]{2}{*}{ Michigan } & 391.8 & 206.0 & -1.0 & -182.9 & 3.506 & \\
\hline & 1.66 & 1.26 & -1.04 & -1.14 & 11.16 & \\
\hline \multirow[t]{2}{*}{ Ohio } & 29.6 & -42.5 & -2.1 & 62.6 & 3.664 & \\
\hline & 0.12 & -0.25 & -2.28 & 0.36 & 9.87 & \\
\hline \multirow[t]{2}{*}{ Wisconsin } & 54.5 & 95.2 & -1.2 & -97.2 & 3.918 & \\
\hline & 0.21 & 0.53 & -1.21 & -0.54 & 12.77 & \\
\hline \multirow[t]{2}{*}{ Iowa } & -195.2 & 159.3 & -2.5 & -30.6 & 3.015 & \\
\hline & -0.93 & 1.13 & -3.10 & -0.21 & 11.56 & \\
\hline Kansas & 118.4 & 91.1 & -1.7 & -67.2 & 3.830 & \\
\hline
\end{tabular}




\begin{tabular}{|c|c|c|c|c|c|}
\hline & 0.45 & 0.51 & -1.67 & -0.37 & 11.00 \\
\hline \multirow[t]{2}{*}{ Minnesota } & 143.9 & 161.8 & -1.9 & -235.4 & 3.342 \\
\hline & 0.64 & 1.06 & -2.27 & -1.51 & 13.15 \\
\hline \multirow[t]{2}{*}{ Missouri } & 67.6 & 117.8 & -2.3 & 17.3 & 3.029 \\
\hline & 0.32 & 0.82 & -2.75 & 0.12 & 9.73 \\
\hline \multirow[t]{2}{*}{ Nebraska } & -355.4 & -9.3 & -2.7 & -125.1 & 4.058 \\
\hline & -1.27 & -0.05 & -2.55 & -0.65 & 12.42 \\
\hline \multirow[t]{2}{*}{ North Dakota } & 180.3 & 149.6 & -2.8 & -48.2 & 3.598 \\
\hline & 0.72 & 0.88 & -2.80 & -0.28 & 9.75 \\
\hline \multirow[t]{2}{*}{ South Dakota } & -188.9 & 69.6 & -3.2 & -125.3 & 3.888 \\
\hline & -0.67 & 0.38 & -3.00 & -0.67 & 9.67 \\
\hline \multirow[t]{2}{*}{ Virginia } & 266.8 & 41.7 & -1.4 & -183.8 & 3.779 \\
\hline & 1.03 & 0.24 & -1.36 & -1.03 & 10.92 \\
\hline \multirow[t]{2}{*}{ Alabama } & 5.5 & 103.0 & -2.9 & 20.4 & 3.553 \\
\hline & 0.02 & 0.61 & -3.00 & 0.12 & 10.24 \\
\hline \multirow[t]{2}{*}{ Arkansas } & 54.9 & 104.7 & -2.9 & -34.6 & 3.538 \\
\hline & 0.22 & 0.63 & -3.05 & -0.21 & 10.05 \\
\hline \multirow[t]{2}{*}{ Florida } & 252.1 & 159.9 & -2.1 & -305.5 & 3.884 \\
\hline & 0.91 & 0.90 & -2.08 & -1.62 & 9.61 \\
\hline \multirow[t]{2}{*}{ Georgia } & 65.6 & 57.4 & -2.5 & -87.9 & 3.951 \\
\hline & 0.24 & 0.31 & -2.48 & -0.47 & 11.46 \\
\hline \multirow[t]{2}{*}{ Louisiana } & 208.0 & 259.3 & -2.4 & -186.5 & 3.339 \\
\hline & 0.87 & 1.62 & -2.68 & -1.17 & 9.46 \\
\hline \multirow[t]{2}{*}{ Mississippi } & 67.7 & 41.0 & -2.8 & -101.5 & 3.581 \\
\hline & 0.27 & 0.25 & -2.92 & -0.60 & 10.25 \\
\hline \multirow[t]{2}{*}{ North Carolina } & 21.8 & 39.8 & -2.6 & -80.6 & 3.786 \\
\hline & 0.08 & 0.23 & -2.71 & -0.45 & 11.06 \\
\hline \multirow[t]{2}{*}{ South Carolina } & 333.9 & 46.8 & -1.9 & 25.5 & 3.484 \\
\hline & 1.32 & 0.28 & -2.05 & 0.15 & 9.95 \\
\hline \multirow[t]{2}{*}{ Texas } & 102.2 & 272.1 & -3.1 & -11.0 & 2.698 \\
\hline & 0.53 & 2.11 & -4.00 & -0.08 & 8.48 \\
\hline \multirow[t]{2}{*}{ Kentucky } & 165.8 & 85.1 & -2.2 & -70.1 & 3.252 \\
\hline & 0.72 & 0.55 & -2.54 & -0.45 & 9.49 \\
\hline \multirow[t]{2}{*}{ Maryland } & 316.4 & 111.5 & 0.5 & -23.0 & 2.890 \\
\hline & 1.36 & 0.65 & 0.44 & -0.12 & 7.14 \\
\hline \multirow[t]{2}{*}{ Oklahoma } & -14.2 & 208.6 & -3.1 & -129.5 & 4.171 \\
\hline & -0.05 & 1.08 & -2.90 & -0.66 & 11.14 \\
\hline \multirow[t]{2}{*}{ Tennessee } & 144.8 & 90.3 & -2.9 & -81.1 & 3.410 \\
\hline & 0.61 & 0.57 & -3.27 & -0.50 & 10.09 \\
\hline West Virginia & -81.5 & 82.9 & -2.0 & -75.1 & 3.408 \\
\hline
\end{tabular}




\begin{tabular}{|c|c|c|c|c|c|}
\hline & -0.33 & 0.52 & -2.12 & -0.47 & 9.44 \\
\hline \multirow[t]{2}{*}{ Arizona } & 311.5 & 346.4 & -1.6 & -253.0 & 3.309 \\
\hline & 1.26 & 1.85 & -1.28 & -1.34 & 5.39 \\
\hline \multirow[t]{2}{*}{ Colorado } & 116.5 & 187.1 & -1.3 & -217.3 & 3.829 \\
\hline & 0.44 & 1.05 & -1.23 & -1.21 & 10.86 \\
\hline \multirow[t]{2}{*}{ Idaho } & 70.4 & 227.1 & -1.9 & -405.0 & 4.428 \\
\hline & 0.23 & 1.11 & -1.67 & -1.99 & 11.28 \\
\hline \multirow[t]{2}{*}{ Montana } & 497.9 & 273.9 & -1.0 & -203.5 & 2.698 \\
\hline & 2.48 & 2.09 & -1.38 & -1.60 & 7.61 \\
\hline \multirow[t]{2}{*}{ New Mexico } & 635.3 & 48.6 & -1.1 & -299.9 & 2.877 \\
\hline & 2.13 & 0.31 & -1.06 & -1.74 & 2.74 \\
\hline \multirow[t]{2}{*}{ Nevada } & 410.8 & 288.0 & -1.6 & -166.7 & 3.262 \\
\hline & 1.71 & 1.88 & -1.75 & -1.03 & 7.77 \\
\hline \multirow[t]{2}{*}{ Utah } & 62.8 & 190.3 & -0.7 & -604.0 & 6.194 \\
\hline & 0.15 & 0.72 & -0.44 & -2.03 & 9.90 \\
\hline \multirow[t]{2}{*}{ Wyoming } & 63.4 & 90.6 & -0.5 & -447.4 & 4.255 \\
\hline & 0.21 & 0.44 & -0.45 & -2.21 & 7.57 \\
\hline \multirow[t]{2}{*}{ California } & 483.1 & 401.7 & -1.6 & 268.6 & 0.825 \\
\hline & 2.68 & 3.81 & -3.05 & 2.02 & 0.89 \\
\hline \multirow[t]{2}{*}{ Oregon } & 308.8 & 340.8 & -1.2 & -82.9 & 1.940 \\
\hline & 1.94 & 3.41 & -1.92 & -0.81 & 5.69 \\
\hline \multirow[t]{2}{*}{ Washington } & 700.0 & 418.9 & -0.3 & -111.6 & 2.002 \\
\hline & 4.56 & 4.07 & -0.46 & -1.03 & 5.68 \\
\hline
\end{tabular}


Appendix Table 3

Means and Standard Deviations of the Housing Market Variables in the Estimation Samples

\begin{tabular}{ll} 
All & \multicolumn{1}{l}{ Counties } \\
Counties for & Under \\
Table 1 & 50,000 for \\
& Table 2 \\
2858 & 2464 \\
1634.3 & 1445.5 \\
897.2 & 694.2 \\
10.9 & 9.8 \\
5.8 & 4.7 \\
3955.8 & 1405.9 \\
14684.0 & 1273.8 \\
5650.0 & 1500.6 \\
39999.0 & 1299.8
\end{tabular}

Number of Observations

Median Value of Owned Home, 1940

Median Rent

Number of Nonfarm Home

Owners

273.8

Number of Nonfarm Renters

39999.0

1299.8 


\section{REFERENCES}

Bodenhorn, Howard. "State Interest Rates, Annually." Dataset available at http://people.clemson.edu/ bodnhrn/DataFiles.htm, February 18, 2010.

Bodenhorn, Howard. "A More Perfect Union: Regional Interest Rates in the Twentieth Century United States." In Anglo-American Financial Systems: Institutions and Markets in the Twentieth Century, pp. 415-53. Edited by Michael Bordo and Richard Sylla. Burr Ridge, Illinois: Irwin, 1996.

Carliner, Michael S., "Development of Federal Homeownership 'Policy'," Housing Policy Debate 9 (no. 2, 1998), 299-321.

Chevan, Albert. “The Growth of Home Ownership, 1940-1980,” Demography 26 (May 1989), 249-66.

Christie, Les. "Renewed HOPE for Homeowners.” CNNMoney website. May 5, 2009. Downloaded from http://money.cnn.com/2009/05/20/real_estate/new_hope_for_homeowners/index.htm on January 13, 2010.

Clarke, Jeanne Nienaber, Roosevelt's Warrior: Harold L. Ickes and the New Deal (Baltimore: Johns Hopkins University Press, 1996).

Comptroller General of the United States. Report on Audit of Home Owners' Loan Corporation for the Fiscal Year Ended June 30, 1949. House Document NO. 446. $81^{\text {st }}$ Congress, $2 \mathrm{~d}$ session. Washington: Government Printing Office, 1950.

Comptroller General of the United States. Report on Audit of the Financial Statements and Accounts of the Home Loan Bank Board and the Organizations Under Its Supervision for the Year Ended June 30, 1952. House Document No. 52. 83rd Congress, 1st session. Washington: Government Printing Office, 1953.

Comptroller General of the United States. Report on Audit of the Financial Statements and Accounts of the Home Loan Bank Board and the Organizations Under Its Supervision. House Document No. 317. 82d Congress, 2d session. Washington: Government Printing Office, 1952.

Courtemanche, Charles and Kenneth Snowden. "Repairing a Mortgage Crisis: HOLC Lending and Its Impact on Local Housing Markets." Working Paper, University of North Carolina, Greensboro, December 2009. Prepared for Session at the ASSA Meetings in Atlanta Georgia in January 2010. 
Englehardt, Gary. “Consumption, Down Payments, and Liquidity Constraints.” Journal of Money, Credit, and Banking 28 (May 1996): 255-271.

Englehardt, Gary and Christopher Mayer. "Intergenerational Transfers, Borrowing Constraints, and Saving Behavior: Evidence from the Housing Market." Journal of Urban Economics 44 (July 1998): 135-57.

Federal Home Loan Bank Board. Fifth Annual Report of the Federal Home Loan Bank Board for the period July 1, 1936, to June 30, 1937. House Document No. 515, $75^{\text {th }}$ Congress, $3^{\text {rd }}$ Session. Washington: Government Printing Office, 1938.

Federal Home Loan Bank Board. Seventh Annual Report of the Federal Home Loan Bank Board for the period July 1, 1938, to June 30, 1939. House Document No. 535, $76^{\text {th }}$ Congress, $3^{\text {rd }}$ Session. Washington: Government Printing Office, 1940.

Field, Alexander. "Uncontrolled Land Development and the Duration of the Depression in the United States.” Journal of Economic History 52 (December 1992), 785-805.

Fishback, Price V., Michael R. Haines, and Shawn Kantor, "The Impact of New Deal Programs on Black and White Infant Mortality in the South," Explorations in Economic History 38 (Jan. 2001), 93-122.

Fishback, Price V., William C. Horrace, and Shawn Kantor, "Do Federal Programs Affect Internal Migration? The Impact of New Deal Expenditures on Mobility During the Great Depression.” National Bureau of Economic Research Working Paper 8283. 2001a.

, "The Impact of New Deal Expenditures on Local Economic Activity: An Examination of Retail Sales, 1929-1939." National Bureau of Economic Research Working Paper 8108. $2001 b$.

Fishback, Price, Shawn Kantor, and John Wallis. “Can the New Deal's Three R's Be Rehabilitated? A Program-by-Program, County-by-County Analysis with Shawn Kantor and John Wallis. NBER Working Paper 8903, 2002.

Fleck, Robert K., "The Marginal Effect of New Deal Relief Work on County-Level Unemployment Statistics.” Journal of Economic History 59 (September 1999a), 659-87.

, "The Value of the Vote: A Model and Test of the Effects of Turnout on Distributive Policy," Economic Inquiry 37 (October 1999b), 609-23.

, "Population, Land, Economic Conditions, and the Allocation of New Deal Spending." Explorations in Economic History 38 (April 2001), 296-304.

Gardner, J., Cohen, W., 1992. Demographic Characteristics of the Population of the United States, 1930-1950: County-Level. ICPSR file 0020. 
Garcia-Mila, Theresa, and Therese J. McGuire, "The Contribution of Publicly Provided Inputs to States' Economies,” Regional Science and Urban Economics, 22 (June 1992), 229-41.

Glaeser, Edward L., and Joseph Gyourko, "Urban Decline and Durable Housing," National Bureau of Economic Research Working Paper 8598, November 2001.

Goodman, John L., Jr., and Joseph B. Nichols, "Does FHA Increase Home Ownership or Just Accelerate It?" Journal of Housing Economics 6 (June 1997), 184-202.

Gorton, Gary. "Information, Liquidity, and the (Ongoing) Panic of 2007." American Economic Review Papers and Proceedings 99: 567-72.

Grebler, Leo, David M. Blank, and Louis Winnick, Capital Formation in Residential Real Estate: Trends and Prospects (Princeton, NJ: Princeton University Press, 1956).

Haines, Michael. Historical, Demographic, Economic, and Social Data: The United States, 1790-2000, Computerized data tapes from ICPSR.

Harris, C. Lowell, History and Policies of the Home Owners' Loan Corporation, National Bureau of Economic Research Financial Research Program: Studies in Urban Mortgage Financing (New York: National Bureau of Economic Research, Inc. 1951).

Haurin, Donald R., Patric Hendershott, and Susan Wachter, "Borrowing Constraints and the Tenure Choice of Young Households," Journal of Housing Research 8 (no. 2, 1997), 13754.

Home Affordable Modification Program. "Making Home Affordable Program. Servicer Performance Report Through January 2010." Downloaded from http://www.financialstability.gov/docs/press/January\%20Report\%20FINAL\%2002\%201 6\%2010.pdf on February 18, 2010.

Home Owners' Loan Corporation. Minutes of the Meetings of the Board of the Home Owners' Loan Corporation, Various dates between 1933 and 1935. Record Group 195 and Entry 1 at National Archives II in College Park, Maryland.

Keoun, Bradley. "Citigroup Expands Use of FDIC Mortgage-Relief Program (Update1)." Bloomberg.com, February 4, 2009. Downloaded from http://www.bloomberg.com/apps/news?pid=20601087\&sid=aHy.f5A TKNg\&refer=hom e\# on January 13, 2010.

Hines, James R. Jr., and Richard H. Thaler, “The Flypaper Effect,” Journal of Economic Perspectives, 9 (Fall 1995), 217-26.

Inter-University Consortium for Political and Social Research, United States Historical Election Returns, 1824-1968, ICPSR Number 0001. Computerized data tapes from ICPSR. 
Linneman, Peter D. and Susan Wachter. "The Impacts of Borrowing Constraints on Homeownership" American Real Estate and Urban Economics Association Journal 17 (Winter 1989), 389-402.

Mason, Joseph. 2001. "Do Lenders of Last Resort Policies Matter? The Effects of the Reconstruction Finance Corporation Assistance to Banks During the Great Depression." Journal of Financial Services Research 20 (September): 77-95.

Mason, Joseph and Daniel Schiffman. 2004. "Too-Big-to-Fail, Government Bailouts, and Managerial Incentives: The Case of Reconstruction Finance Corporation Assistance to the Railroad Industry During the Great Depression."

Moulton, Brent R., "An Illustration of a Pitfall in Estimating the Effects of Aggregate Variables on Micro Unit," Review of Economics and Statistics, 72 (May 1990), 334-38.

Olson, James S., Saving Capitalism: The Reconstruction Finance Corporation and the New Deal, 1933-1940 (Princeton, NJ: Princeton University Press, 1988).

Petree, John. "Report of the Functions of theVarious Federal Emergency Agencies for Alabama, December 13, 1934" from Periodical Reports of State Directors, 1934-1938. Office of Government Reports, Record Group 44, National Archives, Entry 29, Box 392. 1934.

Rand McNally, Commercial Atlas and Marketing Guide. New York: Rand McNally, 1943.

Romer, Christina D., “Why Did Prices Rise in the 1930s?” Journal of Economic History, 59 (March 1999), 167-99.

Rose, Jonathan D. “The Incredible HOLC? Mortgage Relief During the Great Depression. Unpublished working paper, Board of Governors, Federal Reserve, November 2009.

Rosen, Harvey S. and Kenneth T. Rosen, "Federal Taxes and Homeownership: Evidence from Time Series," Journal of Political Economy 88 (February 1980), 59-75.

Sechrist, Robert P. Basic Geographic and Historic Data for Interfacing ICPSR Data Sets, 16201983 (United States). Data set. Inter-university Consortium for Political and Social Research, Spring 1984.

Schlesinger, Arthur, The Age of Roosevelt: The Coming of the New Deal (Boston: HoughtonMifflin, 1958).

Snowden, Kenneth The Anatomy of a Residential Mortgage Crisis: A Look Back to the 1930s.” Working Paper at the University of North Carolina, Greensboro. June 2009.

U.S. Bureau of the Census, Birth, Stillbirth and Infant Mortality Statistics for the Continental United States (Washington, DC: Government Printing Office, various years).

U.S. Bureau of the Census, Historical Statistics of the United States: Colonial Times to 1970 (Washington, DC: GPO, 1975). 
U.S. Bureau of the Census, Fifteenth Census of the United States: Population, Volume VI, Families. Vol. 6 (Washington DC: GPO, 1933).

U.S. Bureau of the Census. Mortgages on Homes: A Report on the Results of the Inquiry As to the Mortgage Debt on Homes Other Than Farm Homes at the Fourteenth Census, 1920. Washington, DC: Government Printing Office, 1923.

U.S. Bureau of the Census, Mortality Statistics (Washington, DC: Government Printing Office, various years).

U.S. Bureau of the Census, Sixteenth Census of the United States: 1940, Housing (Washington, DC: GPO, 1943).

U.S. Bureau of the Census, "Illiteracy in the United States, October 1947," Current Population Reports: Population Characteristics, Series P-20 no. 20, September 22, 1948.

U.S. Bureau of Economic Analysis, GNP: An Overview of Source Data and Estimating Methods: Methodology Papers: U.S. National Income and Product Accounts (Washington, DC: GPO, 1987).

U.S. Bureau of Internal Revenue, Statistics of Income for 1930. Washington: Government Printing Office, 1932.

U.S. Congress, Official Congressional Directory, for the $73^{\text {rd }}$ Congress $1^{\text {st }}$ session through $76^{\text {th }}$ Congress (Washington, D.C.: GPO, various years).

U.S. Department of Commerce, Bureau of Foreign and Domestic Commerce, Consumer Market Data Handbook. (Washington, D.C.: GPO, 1936).

U.S. Department of Commerce, Bureau of Foreign and Domestic Commerce, Consumer Market Data Handbook. (Washington, D.C.: GPO, 1939).

U.S. Department of Commerce, Bureau of Foreign and Domestic Commerce, General Consumer Market Statistics, Supplement 1 to the Market Data Handbook of the United States. (Washington, D.C.: GPO, 1932).

U.S. Department of Treasury. Home Affordable Modification Program Guidelines, March 4, 2009. Download from http://www.ustreas.gov/press/releases/reports/modification_program_guidelines.pdf on February 18, 2010.

U.S. Department of Treasury. Making Home Affordable: Summary of Guidelines. March 4, 2009 Downloaded from http://www.ustreas.gov/press/releases/reports/guidelines_summary.pdf on February 18, 2010. 
U.S. Farm Credit Administration, Financing Agriculture in 1934 (Washington, D.C: GPO, 1935).

, Farm Credit Quarterly, June 1936 (Washington, D.C.: GPO, 1936).

U.S. Federal Housing Administration, The FHA Story in Summary, 1934-1959 (Washington, DC: GPO, 1959).

U.S. Federal Housing Administration, Annual Report (Washington, DC: GPO, various years).

U.S. Federal Housing Administration, 1996 Annual Management Report. Located at http://www.hud.gov:80/conrept/apdxc3.pdf.

U.S. Office of Government Reports, Statistical Section, Report No. 9, Volume 1, "Direct and Cooperative Loans and Expenditures of the Federal Government for Fiscal Years 1933 through 1939." Mimeo, 1940a.

U.S. Office of Government Reports, Statistical Section, Report No. 10, Volume 1, "County Reports of Estimated Federal Expenditures March 4 1933-June 30, 1939,” Mimeo, $1940 b$.

Wallis, John Joseph, "Employment, Politics, and Economic Recovery During the Great Depression," Review of Economics and Statistics, 69 (Aug. 1987), 516-20.

, "The Political Economy of New Deal Spending Revisited, Again: With and Without Nevada," Explorations in Economic History 35 (April 1998), 140-70.

, "The Political Economy of New Deal Spending, Yet Again: A Reply," Explorations in Economic History 38 (April 2001), 305-14.

Wallis, John Joseph, and Daniel K. Benjamin, "Public Relief and Private Employment in the Great Depression,” Journal of Economic History, 41 (Mar. 1981), 97-102.

, "Private Employment and Public Relief During the Great Depression," Department of Economics, University of Maryland working paper, 1989.

Zibel, Alan. "A Year Later, Things Look Bleak for Obama's Housing Strategy." Associated Press downloaded from http://azstarnet.com/news/national/article b7b16b27-7cb6-5795a5cc-0a05e961e 78f.html?print=1 on February 18, 2010

Zorn, Peter. "Mobility-Tenure Decisions and Financial Credit: Do Mortgage Qualification Requirements Constrain Homeownership?" American Real Estate and Urban Economics Association Journal, 17 (Spring 1989), 1-16. 


\section{ENDNOTES}

${ }^{1}$ See Home Affordable Mortgage Program (2010) for program statistics through January. Borrowers are considered at risk if they are 60 days or more delinquent on the loan Zibel 2010). The loans eligible for the program are first-lien loans originated on owner-occupied properties with unpaid principal balances of up to $\$ 729,750$. Borrowers must fully document income. The loan servicer performs a net present value test on the cash flow from loans at risk of imminent default in two scenarios: with and without default. If there is no fraud or contract prohibition, the lender is expected to modify the loan if the modified NPV is higher than the unmodified NPV. Loan services are required to follow a sequence of steps involving reducing the interest rate on the loan (to a floor of 2 percent) and then extending the term or amortization of the loan to 40 years, and then if necessary forbearing the principal Homes Affordable Mortgage Program (U.S. Department of Treasury, March 4, 2009). A Home Affordable Refinance program was made available to 4 to 5 million homeowners whose loans are owned by Fannie Mae and Freddie Mac. The borrower had to have a solid payment history and the home values had to have fallen so that the loan to value ratios is now above 80 percent (U.S. Department of Treasury March 4, 2009). Several other programs were announced in 2008 but seem to have been more limited in scope. Hope for Homeowners $(\mathrm{H} 4 \mathrm{H})$ was passed in summer 2008 and took effect on October 1, 2008. It was designed to allow lenders to move borrowers into government-insured loans while reducing loan balances to 90 percent of the market value of the home. Anticipated to help about 400,000 home owners over three years, only one borrower had been helped by May 2009 (Christie, 2009). In the fall of 2008 Freddie Mac and Fannie Mae announced stream-lined procedures to shift several 
hundred thousand borrowers who were more than 90 days behind on their mortgage, living in the home, not in bankruptcy, and owing over 90 percent of home value into mortgages with monthly payments equal to 38 percent of their monthly income. In December 2008, the Federal Deposit Insurance Corporation announced that it would modify 2 million loans at a taxpayer cost of $\$ 24$ billion to move the monthly payment to 31 percent of pre-tax income with lower rates, longer terms, forbearance on the principal. By February 2009, most of the loans modified under the program had been held by failed banks, although the FDIC had begun requiring that some banks receiving bailout funds also use the program's procedures (Keoun, 2009).

${ }^{2}$ Glaeser and Gyourko (2001) argue that negative economic shocks lead to decreases in housing prices that are greater in absolute value than decreases in population. During the 1930s, nearly every geographic area experienced a negative shock between 1929 and 1933 and despite recovery in real incomes to 1929 levels by the end of the decade, the unemployment rate remained above 10 percent for the rest of the decade. The comparisons here show that a severe negative shock can have a substantial negative effect on housing values that can last for an extended period of time.

${ }^{3}$ The Building and Loans combined two contracts to create an amortized loan. One contract was the standard mortgage (interest only with balloon of principal) and the other was a subscription to buy shares in the Building and Loan association in installments that added up to the principal of the loan. The money for the shares went into a sinking fund for the association, and after 11 or 12 years enough had accumulated to cancel the debt on the principal. Since the borrowers were now members of the 
association, the sinking fund feature created problems in the 1930s when many people failed to finish paying into the fund. Those who were still paying in had to increase their share payments to get the debts of the Building and Loan cancelled. This gave many borrowers even more incentive to stop making share payments and many Building and Loans were frozen and then worked to liquidate the loans and the real estate on behalf of the members of the association. See Snowden 2009.

${ }^{4}$ The HOLC's shift to longer term amortized mortgages with lower down payments coincided with and likely contributed to a shift in the terms in the entire mortgage market. Data from Grebler, Blank, and Winnick $(1956,236)$ on loans for 1-to4-family houses made by commercial banks, savings and loan associations, and life insurance companies show a 50 percent rise in the average contract length of loans and a 16 percent rise in the loan-to-value ratio between 1930-34 and 1935-1939. The average nominal interest rate also fell by 12 percent (roughly one percentage point).

${ }^{5}$ Cumulative earnings from interest and dividends from the HOLC's \$224 million investments in Federal Savings and Loan Associations and state-chartered members of the Federal Home Loan Bank System or insured by the Federal Savings and Loan Insurance Corporation added $\$ 44.8$ million to the plus side of the HOLC balance sheet. Dividends on investments in the FSLIC added another $\$ 28$ billion from inception through 1951 (Comptroller General of the United States 1949, 6; 1952, 27).

${ }^{6}$ See, for example, Englehardt 1996, Engelhardt and Mayer 1998, Haurin, Hendershott, and Wachter 1997, Linneman and Wachter 1989, and Zorn 1989). 
${ }^{7}$ Instead of describing the HOLC as increasing demand with its loans, another way to describe it is as reducing the supply of housing that would have been dumped on the market through foreclosures, which would have driven home ownership values down, the number of homeowners down, increased the number of renters, and potentially raised rents. Thus, the causal effect of the HOLC through this mechanism would have been to raise housing values, raise the number of home owners, reduce the number of renters, and reduce rents.

${ }^{8}$ For definitions of the variables, see U.S. Bureau of the Census, Housing, 1943, Volume I, Part 1, pp. 1-7 and U.S. Bureau of the Census, Families, 1933, Vol. IV, pp. 511. The 1930 census asked questions about families, while the 1940 census asked questions about dwelling units. Thus, the 1940 census contains information on vacant dwelling units that are unavailable in the 1930 census.

${ }^{9}$ Given the costs of moving, each homeowner's decision to choose to stay in his own home, purchase a new home, or move to a rental in the next year will be influenced by his current status. Owners of rental property typically find it costly and time consuming to change the property in ways that make it attractive as owned property, and vice versa. Renters have more mobility but still face some costs to switch. In the analysis data availability requires a ten-year lag. The persistence might be weaker across a ten-year period, although cross-sectional regressions show a very strong relationship between the 1940 and 1930 levels.

${ }^{10}$ There was a 1920 mortgage census that collected information only on the value of mortgaged homes and was limited in the scope of cities for which it reported 
information. The 1920 census collected information on home ownership but the published census did not report the number of nonfarm owners and the number of nonfarm renters separately. Since the IPUMS sample is a one percent sample and the number of observations of households in about half the counties is small enough there may be measurement error.

${ }^{11}$ We considered an alternative strategy in which we used the minutes of the HOLC oversight committee in the National Archives to determine the date in which the office first opened. The HOLC gave out loans in such a short period, we thought offices that opened later would have been at a disadvantage in distributing loans. Here again, there are worries that the date of opening was determined by the extent of problems with troubled loans.

${ }^{12}$ We experimented with different location algorithms starting with only the largest city in each state, and then adding the second, then third, then fourth largest cities. Using the four largest cities along with the state capital leads to the strongest instrument.

${ }^{13}$ There was an HOLC office in the state capital in 37 of the 48 states, in 42 counties that had a state's largest population, and in 37,26 , and 20 of the counties with the second, third, and fourth largest populations respectively.

${ }^{14}$ The New Deal program most closely correlated with the HOLC is the FHA with a correlation between logged values of 0.5 . Correlations with the other programs are 0.30 with the RFC, 0.176 with the public works and relief, -0.136 with the AAA, and 0.19 with the farm loans. 
${ }^{15}$ When we use the data set we created and use our instrument strategy in a crosssectional model for 1940 with lagged housing values in 1930, we find results that are similar to those found by Courtemanche and Snowden (2009). The results are available from the authors. Although they do not focus on rental markets, they do find that the HOLC is associated with a rise in home ownership rates. Our results, in contrast, suggest that the HOLC increases the number of renters by more than the number of homeowners. 